
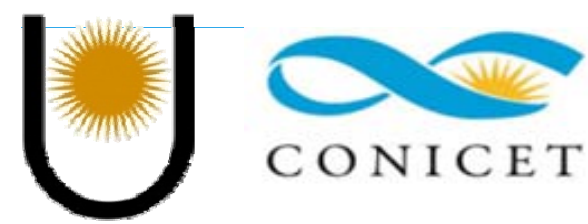

C O N I C E T

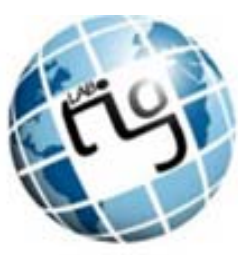

Departamento de Geografía Facultad de Humanidades

Universidad Nacional del Nordeste

\section{IDENTIFICACIÓN DE PROCESOS ATMOSFÉRICOS MEDIANTE IMÁGENES DE SATÉLITE}

Material didáctico utilizado en la ásignatura Climatología y en el Curso de Capacitación homónimo (11 de diciembre de 2015)

Dictantes: Prof. Dr. Luis Pyszczek Prof. Patricia Snaider Cátedra de Climatología

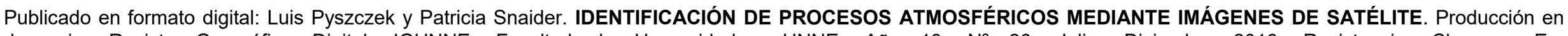

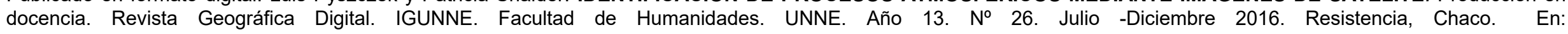
http://hum.unne.edu.ar/revistas/geoweb/default.htm 


\section{CRONOGRAMA}

$1^{\circ}$ parte: Fuentes de Información.

1) Fuentes de Información Meteorológica.

Percepción Remota.

2) Tipos de Imágenes Satelitales utilizados por el Servicio Meteorológico Nacional.

$2^{\circ}$ parte: Procesos atmosféricos.

3) Procesos Atmosféricos. Definición. Génesis de los Procesos Atmosféricos.

4) Nefoanálisis. Carta Sinópticas del Tiempo (Servicio Meteorológico Nacional)

Publicado en formato digital: Luis Pyszczek y Patricia Snaider. IDENTIFICACIÓN DE PROCESOS ATMOSFÉRICOS MEDIANTE IMÁGENES DE SATÉLITE. Producción en docencia. Revista Geográfica Digital. IGUNNE. Facultad de Humanidades. UNNE. Año 13. No 26. Julio -Diciembre 2016. Resistencia, Chaco. En: http://hum.unne.edu.ar/revistas/geoweb/default.htm 


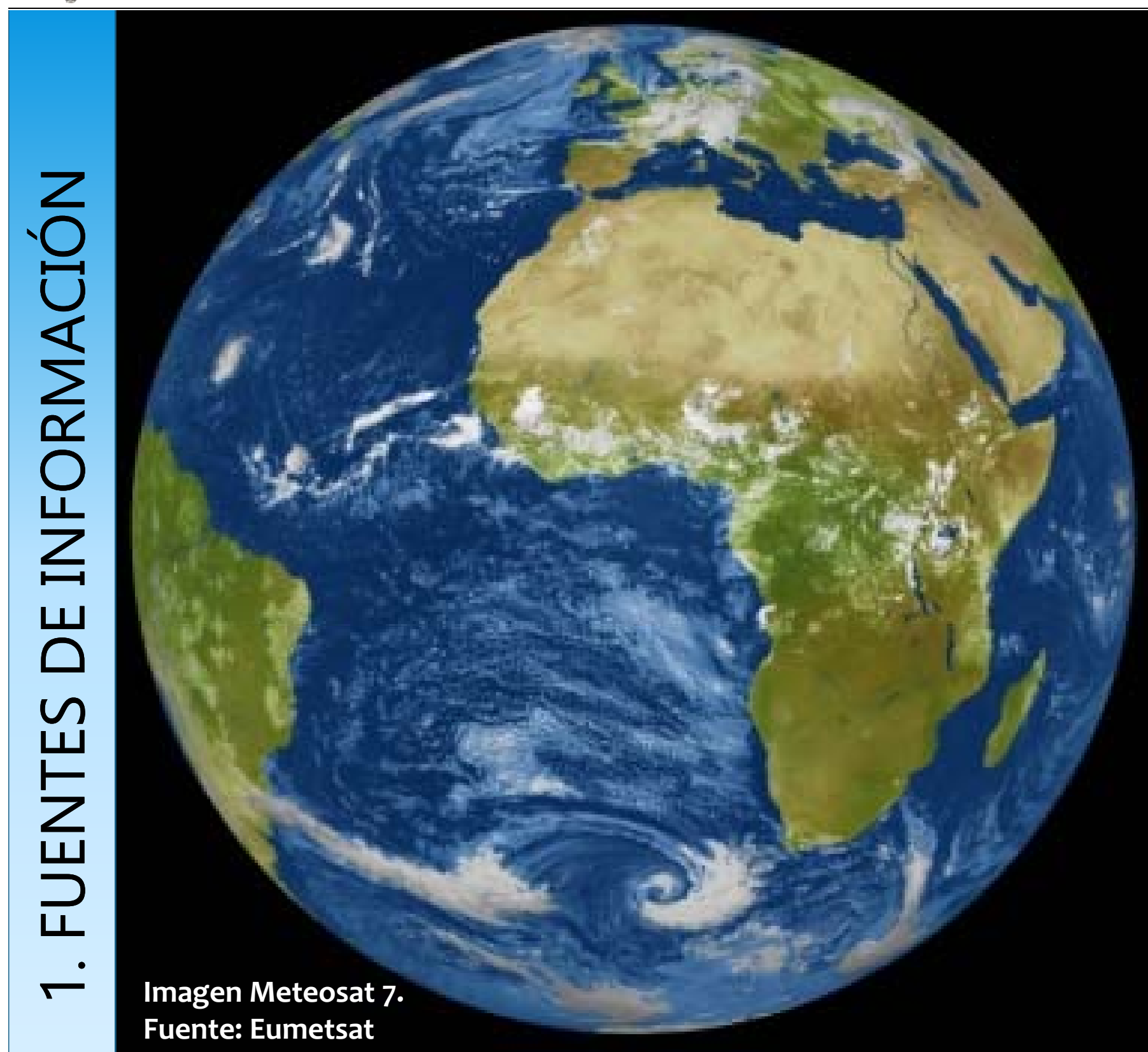

En esta PRIMERA PARTE vemos que las fuentes de información utilizadas para identificar procesos atmosféricos son de dos tipos: una proviene de los observatorios o estaciones meteorológicas ubicadas en la superficie terrestre y la otra se obtiene a través de sensores remotos que están instalados en aviones o satélites.

Aquí nos centramos en la segunda...

Publicado en formato digital: Luis Pyszczek y Patricia Snaider. IDENTIFICACIÓN DE PROCESOS ATMOSFÉRICOS MEDIANTE IMÁGENES DE SATÉLITE. Producción en docencia. Revista Geográfica Digital. IGUNNE. Facultad de Humanidades. UNNE. Año 13. No 26. Julio -Diciembre 2016. Resistencia, Chaco. En: http://hum.unne.edu.ar/revistas/geoweb/default.htm 


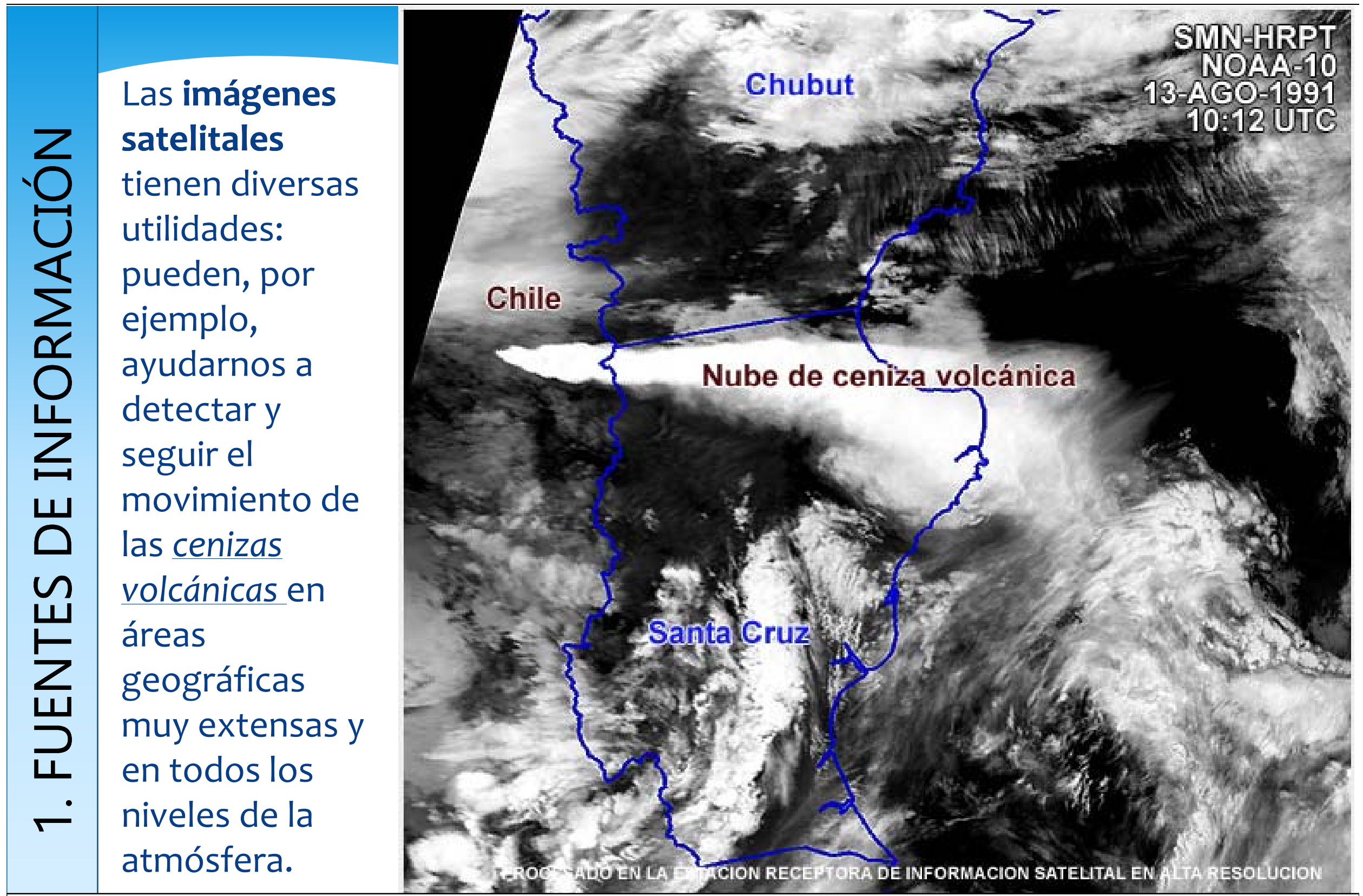

Publicado en formato digital: Luis Pyszczek y Patricia Snaider. IDENTIFICACIÓN DE PROCESOS ATMOSFÉRICOS MEDIANTE IMÁGENES DE SATÉLITE. Producción en docencia. Revista Geográfica Digital. IGUNNE. Facultad de Humanidades. UNNE. Año 13. No 26. Julio -Diciembre 2016. http://hum.unne.edu.ar/revistas/geoweb/default.htm 


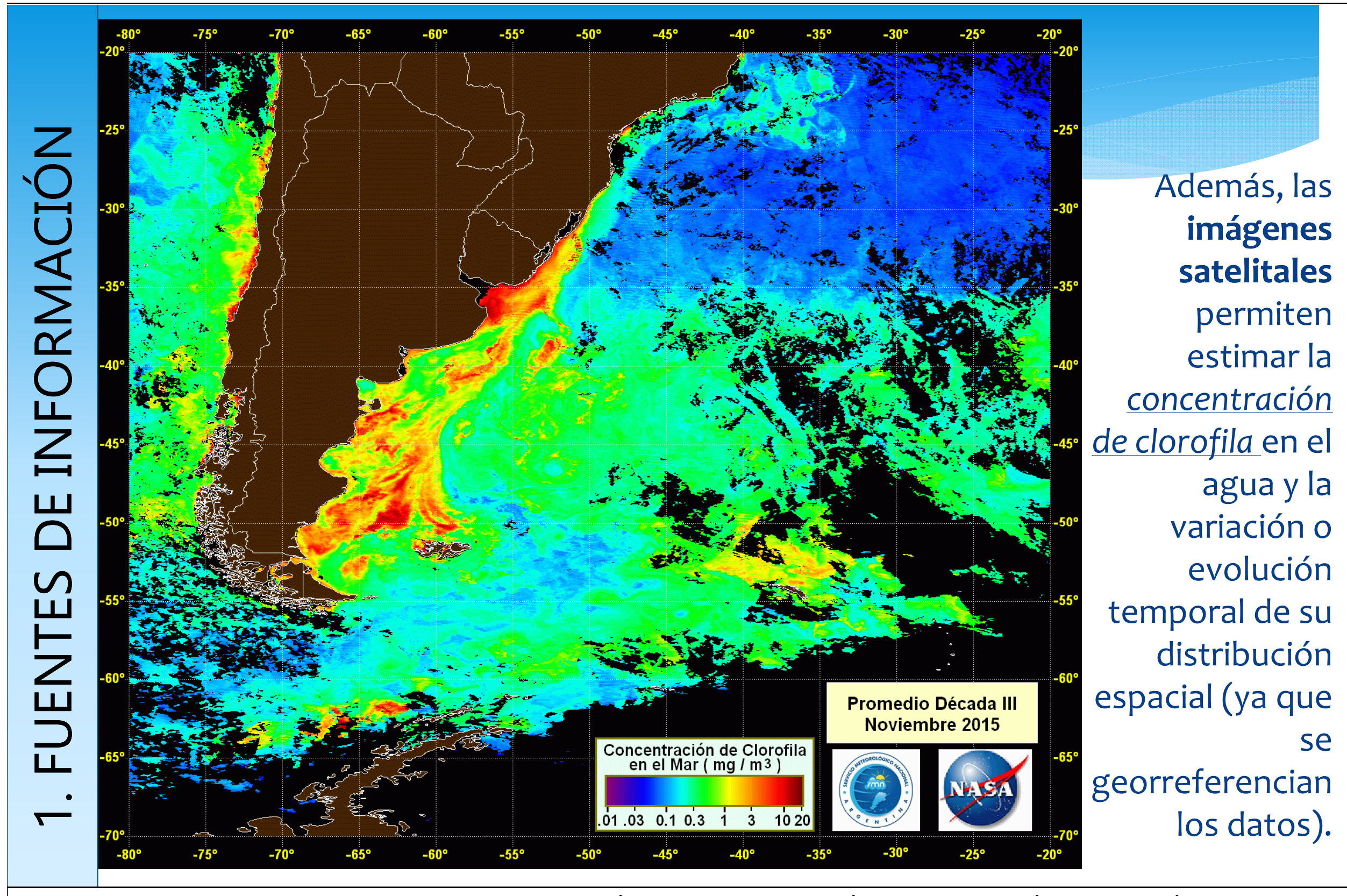

Publicado en formato digital: Luis Pyszczek y Patricia Snaider. IDENTIFICACIÓN DE PROCESOS ATMOSFÉRICOS MEDIANTE IMÁGENES DE SATÉLITE. Producción en docencia. Revista Geográfica Digital. IGUNNE. Facultad de Humanidades. UNNE. Año 13. No 26. Julio -Diciembre 2016. Resistencia, Chaco. En: http://hum.unne.edu.ar/revistas/geoweb/default.htm 


\section{IMÁGENES SATELITALES}

Una imagen satelital es una representación visual de los datos reflejados por la superficie de la tierra que captura un sensor montado en un satélite artificial.

Los datos son enviados a una estación terrena en donde se procesan y se convierten en imágenes, enriqueciendo nuestro conocimiento de las características de la Tierra en diferentes escalas espaciales. (INEGI, 2015)

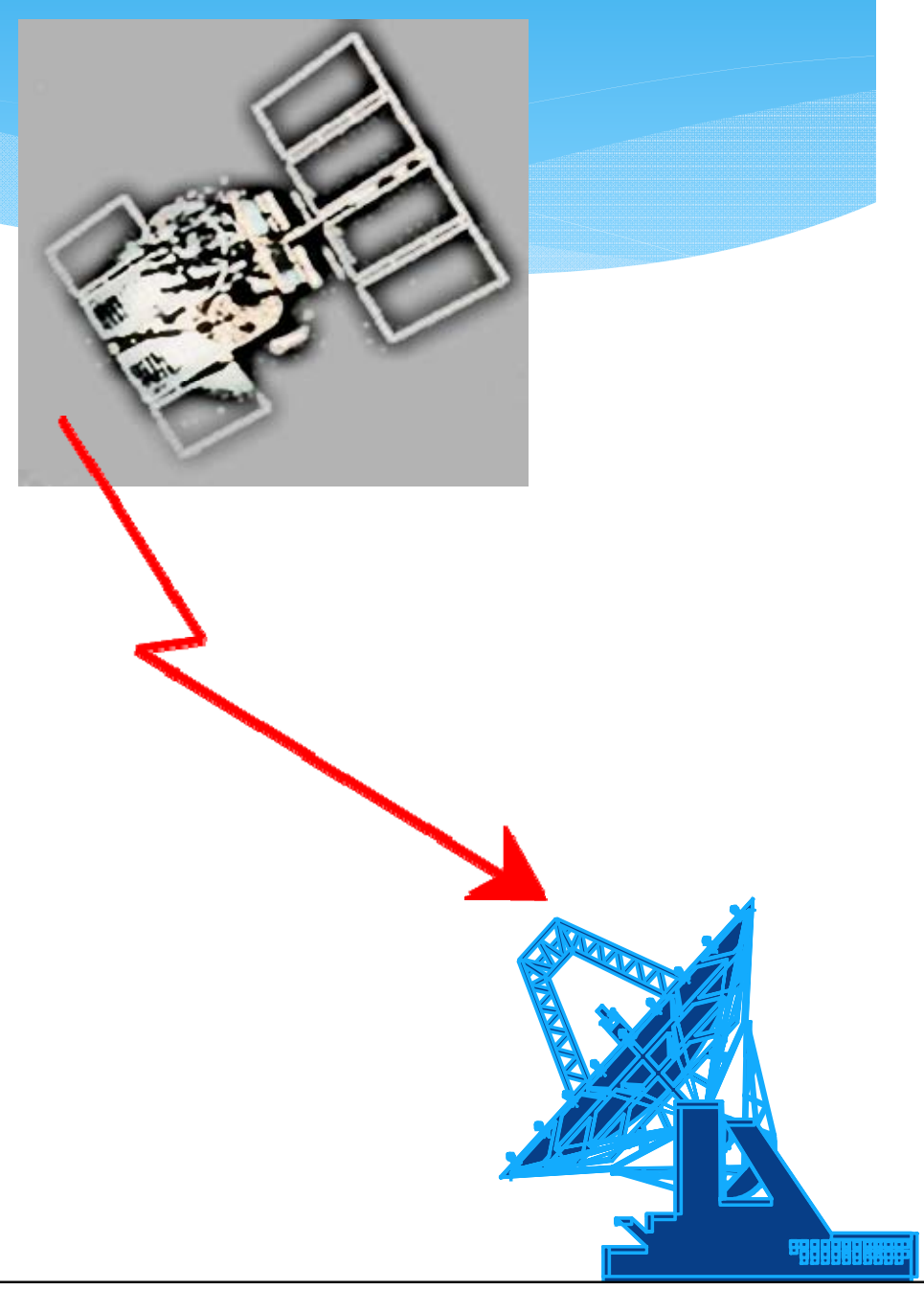

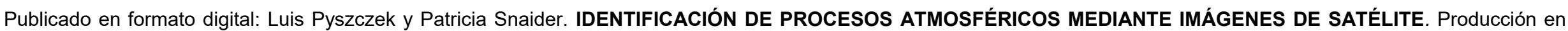

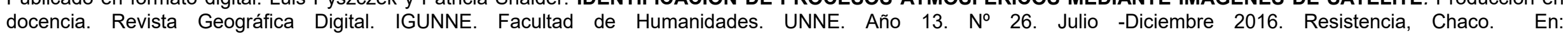
http://hum.unne.edu.ar/revistas/geoweb/default.htm 


\section{SATELITES}

Los satélites meteorológicos proporcionan datos permanentemente actualizados de las condiciones meteorológicas que afectan a grandes áreas geográficas.

u Los servicios de predicción meteorológica dependen del flujo constante de imágenes tomadas por estos satélites. (ZAMORA, 2015)

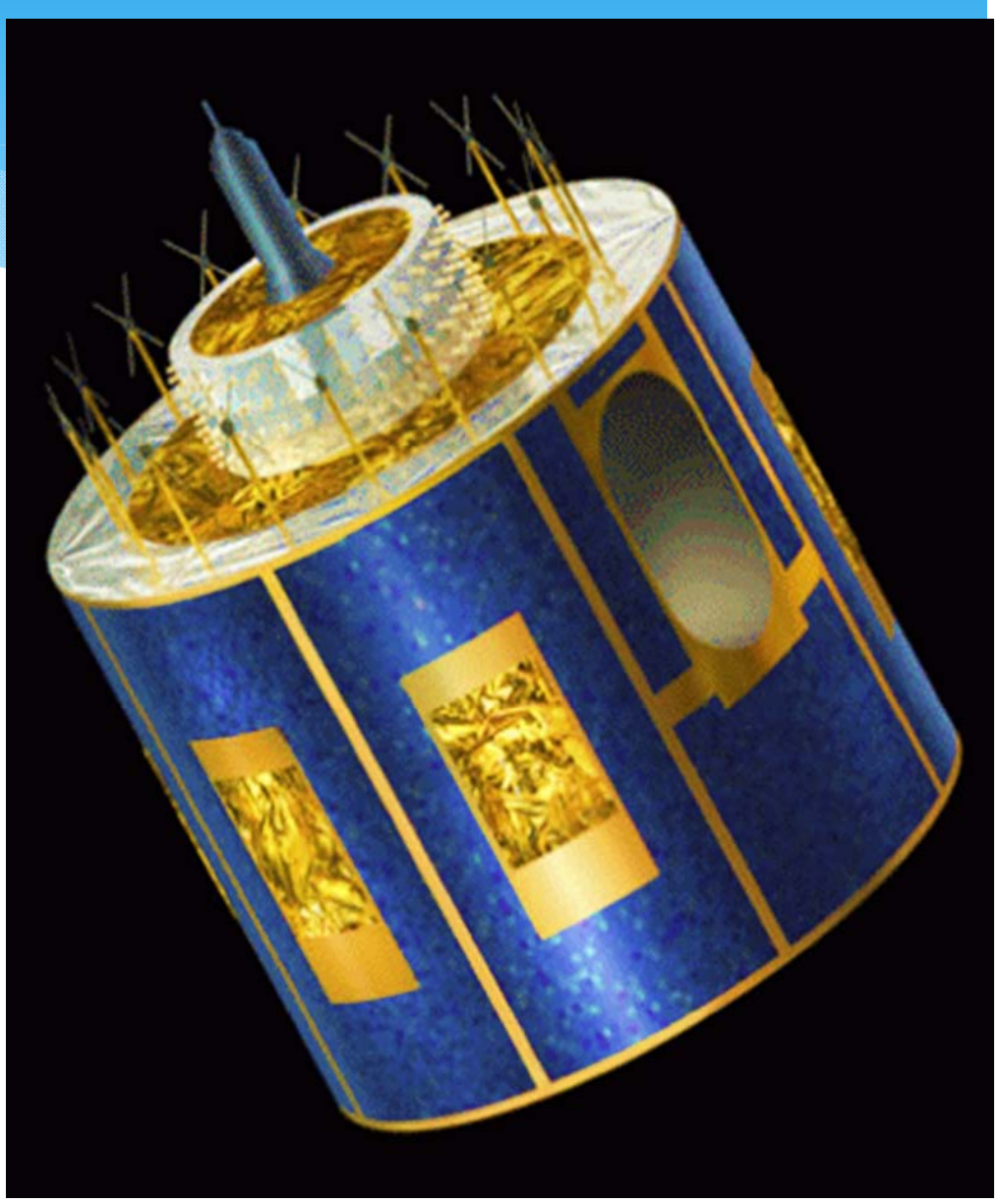

Satélite geoestacionario Meteosat de segunda generación. Créditos: ESA/Ducros

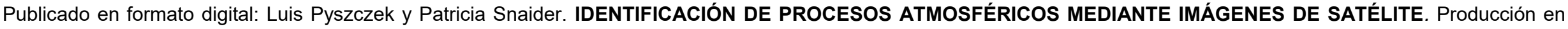

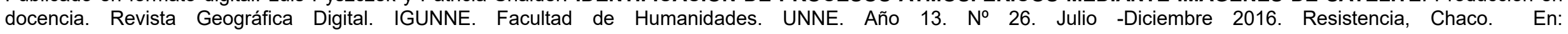
http://hum.unne.edu.ar/revistas/geoweb/default.htm 


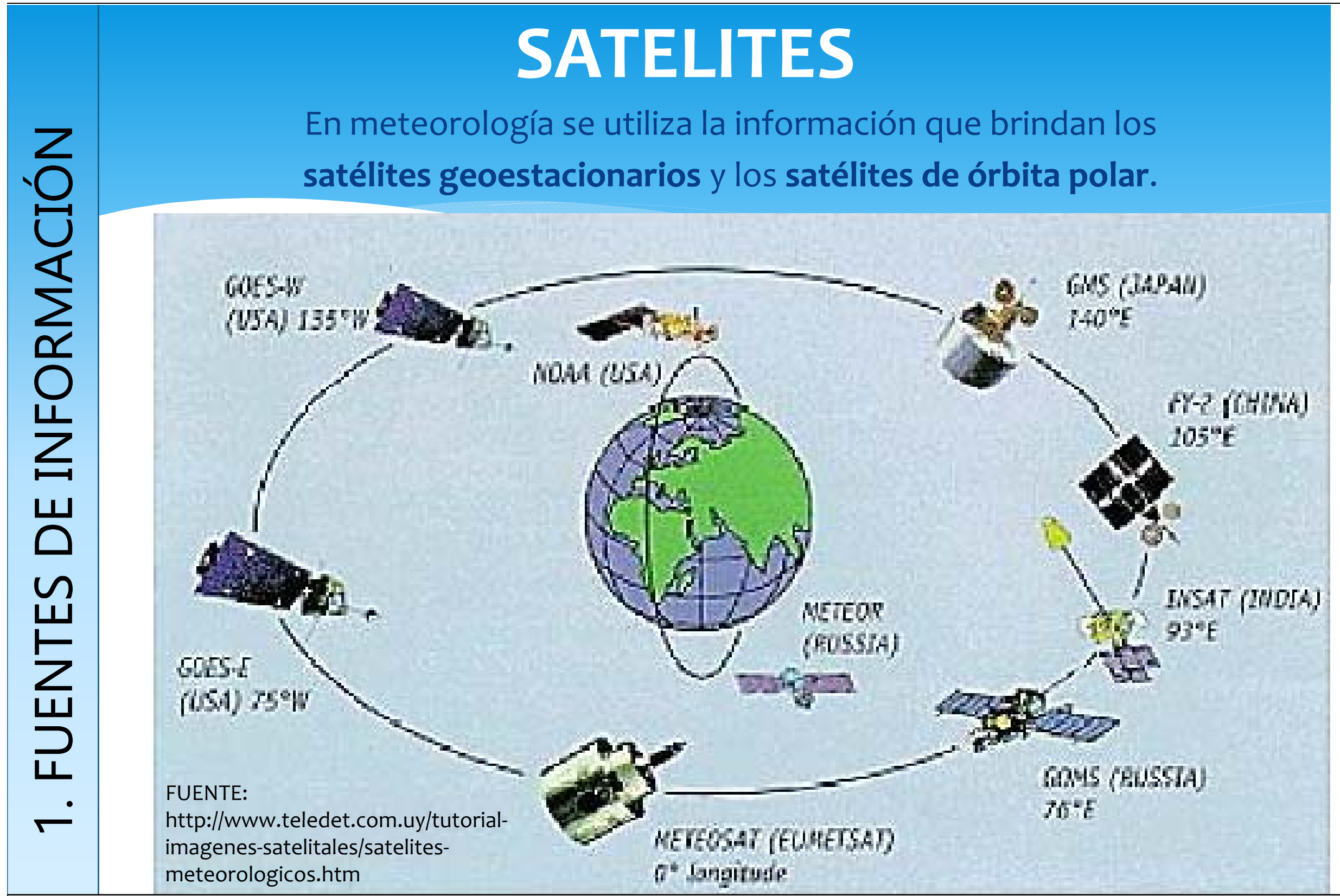

Publicado en formato digital: Luis Pyszczek y Patricia Snaider. IDENTIFICACIÓN DE PROCESOS ATMOSFÉRICOS MEDIANTE IMÁGENES DE SATÉLITE. Producción en docencia. Revista Geográfica Digital. IGUNNE. Facultad de Humanidades. UNNE. Año 13. No 26. Julio -Diciembre $2016 . \quad$ Resistencia, Chaco. En: http://hum.unne.edu.ar/revistas/geoweb/default.htm 


\section{SATELITES GEOESTACIONARIOS}

Los satélites geoestacionarios o satélites geosíncronos describen órbitas sobre el Ecuador terrestre con la misma velocidad angular que la Tierra, es decir, permanecen inmóviles sobre un determinado punto sobre nuestro globo.

Actualmente están operativos cinco satélites geoestacionarios:

GOES E (Este) y GOES W (Oeste) (EE.UU)

GMS (Japón)

GOMS (Rusia)

INSAT (India)

METEOSAT de la Agencia Espacial Europea (ESA)

Este grupo de satélites producen cada media hora imágenes actualizadas de toda la superficie terrestre, exceptuando las regiones polares.

Sus características comunes son:

Alta resolución temporal: 30 minutos.

Baja resolución espacial: 2.5 a 5 km/píxel

Captan las bandas: visible, Infrarrojo térmico y vapor de agua. 


\section{SATELITES GEOESTACIONARIOS}

El Satélite Geoestacionario Operacional Ambiental GOES (Geostationary Operational Environmental Satellite) fue diseñado para operar en órbita geoestacionaria, a $35.790 \mathrm{~km}$ sobre la tierra, permaneciendo estacionario (respecto a un punto sobre el suelo). La nave GOES I-M continuamente cubre el área de EE. UU. continental, los océanos Pacífico y Atlántico, América Central y Sudamérica.

Su función es la de "vigilar" la tierra monitoreando nubes, temperatura superficial y vapor de agua, y sondeando los perfiles verticales de estructuras térmicas y de vapor. Así sigue la evolución de fenómenos de la atmósfera asegurando la cobertura en tiempo real para seguir eventos de corta vida, especialmente severas tormentas locales, ciclón tropical, huracanes, que directamente afectan la seguridad pública, protección de propiedades, y últimamente, salud y desarrollo económico. 


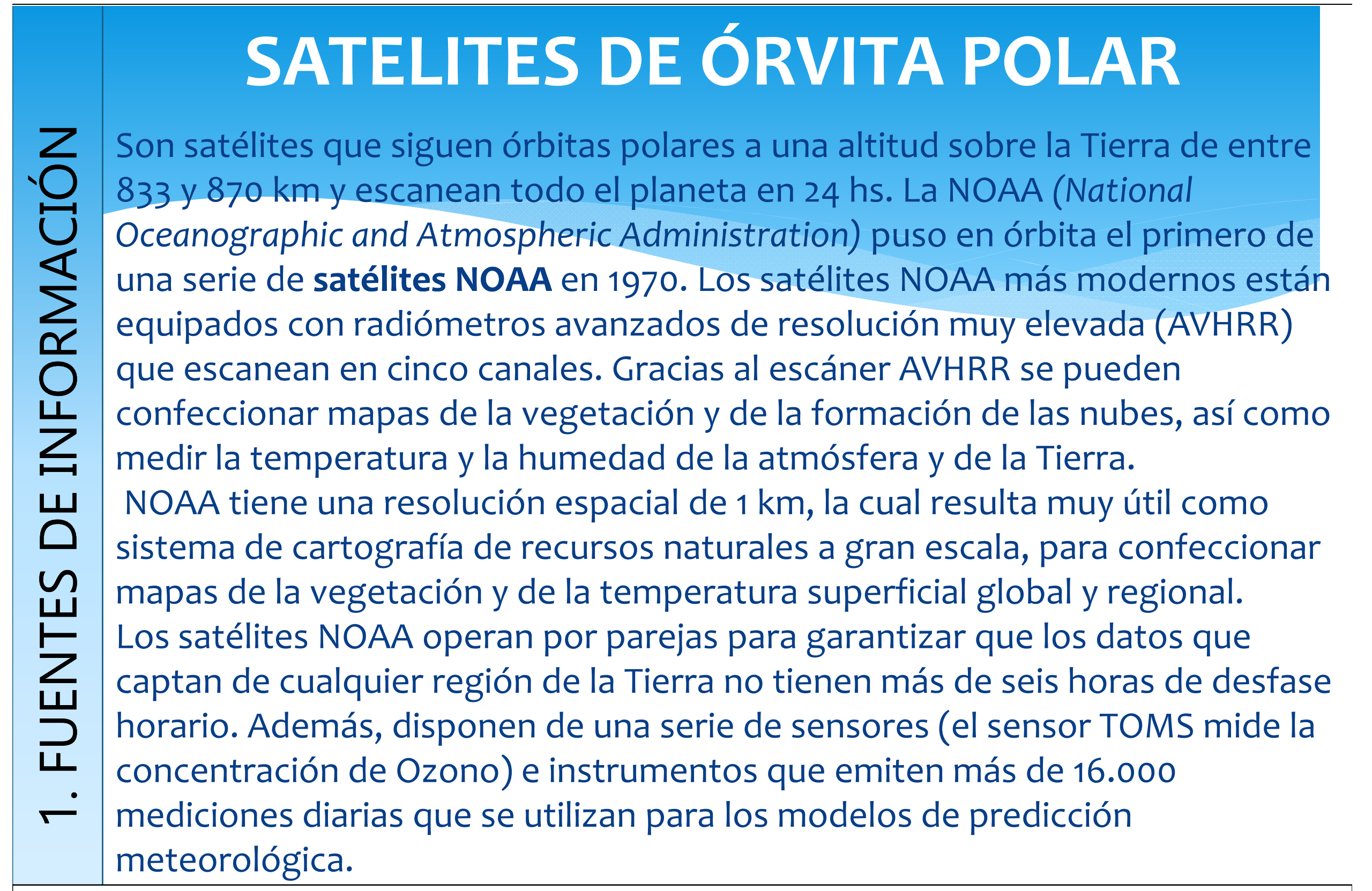

Publicado en formato digital: Luis Pyszczek y Patricia Snaider. IDENTIFICACIÓN DE PROCESOS ATMOSFÉRICOS MEDIANTE IMÁGENES DE SATÉLITE. Producción en docencia. Revista Geográfica Digital. IGUNNE. Facultad de Humanidades. UNNE. Año 13. No 26. Julio -Diciembre 2016. Resistencia, Chaco. En: http://hum.unne.edu.ar/revistas/geoweb/default.htm 


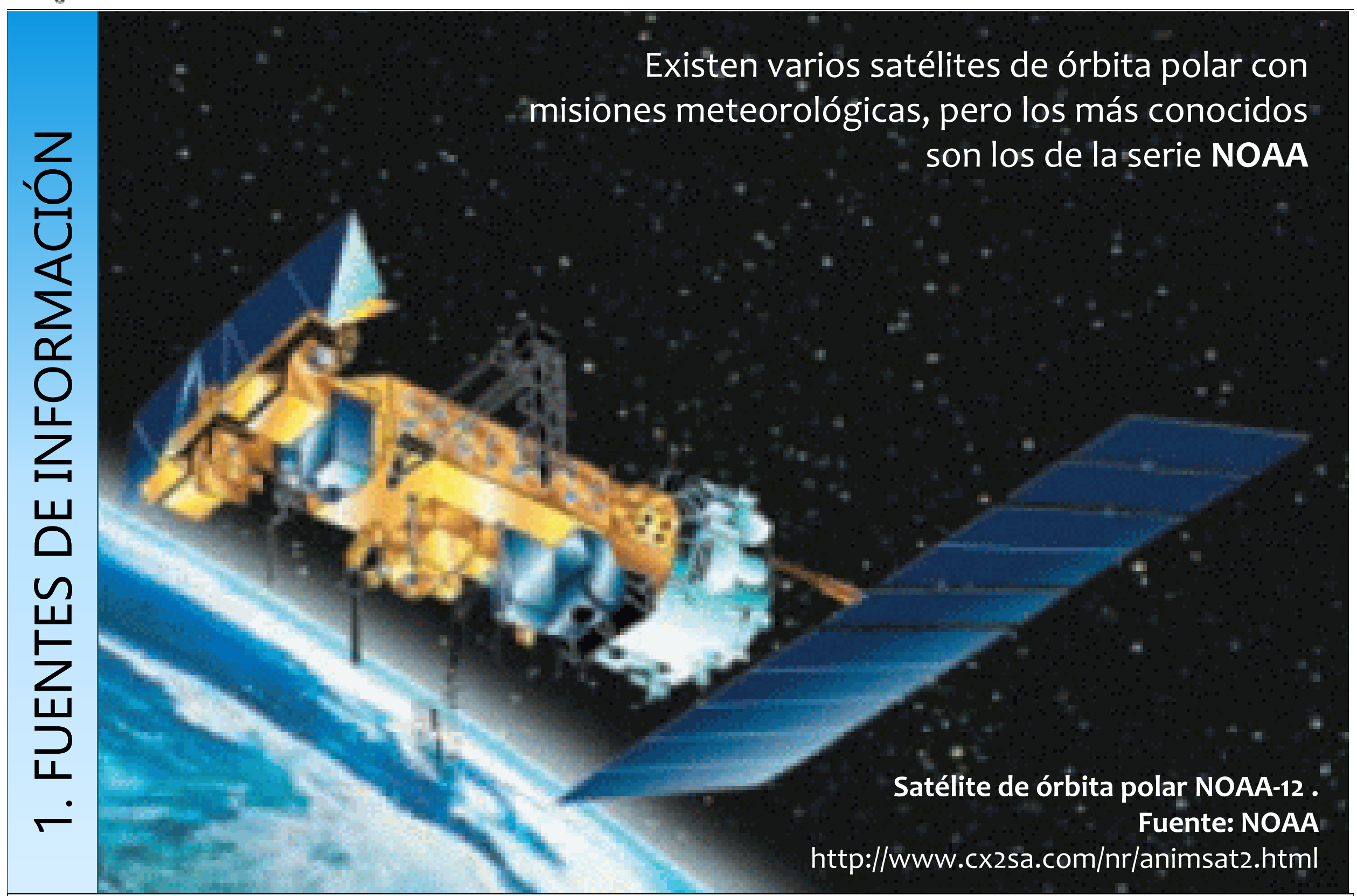

Publicado en formato digital: Luis Pyszczek y Patricia Snaider. IDENTIFICACIÓN DE PROCESOS ATMOSFÉRICOS MEDIANTE IMÁGENES DE SATÉLITE. Producción en docencia. Revista Geográfica Digital. IGUNNE. Facultad de Humanidades. UNNE. Año 13. No 26. Julio -Diciembre 2016. Resistencia, Chaco. En: http://hum.unne.edu.ar/revistas/geoweb/default.htm 


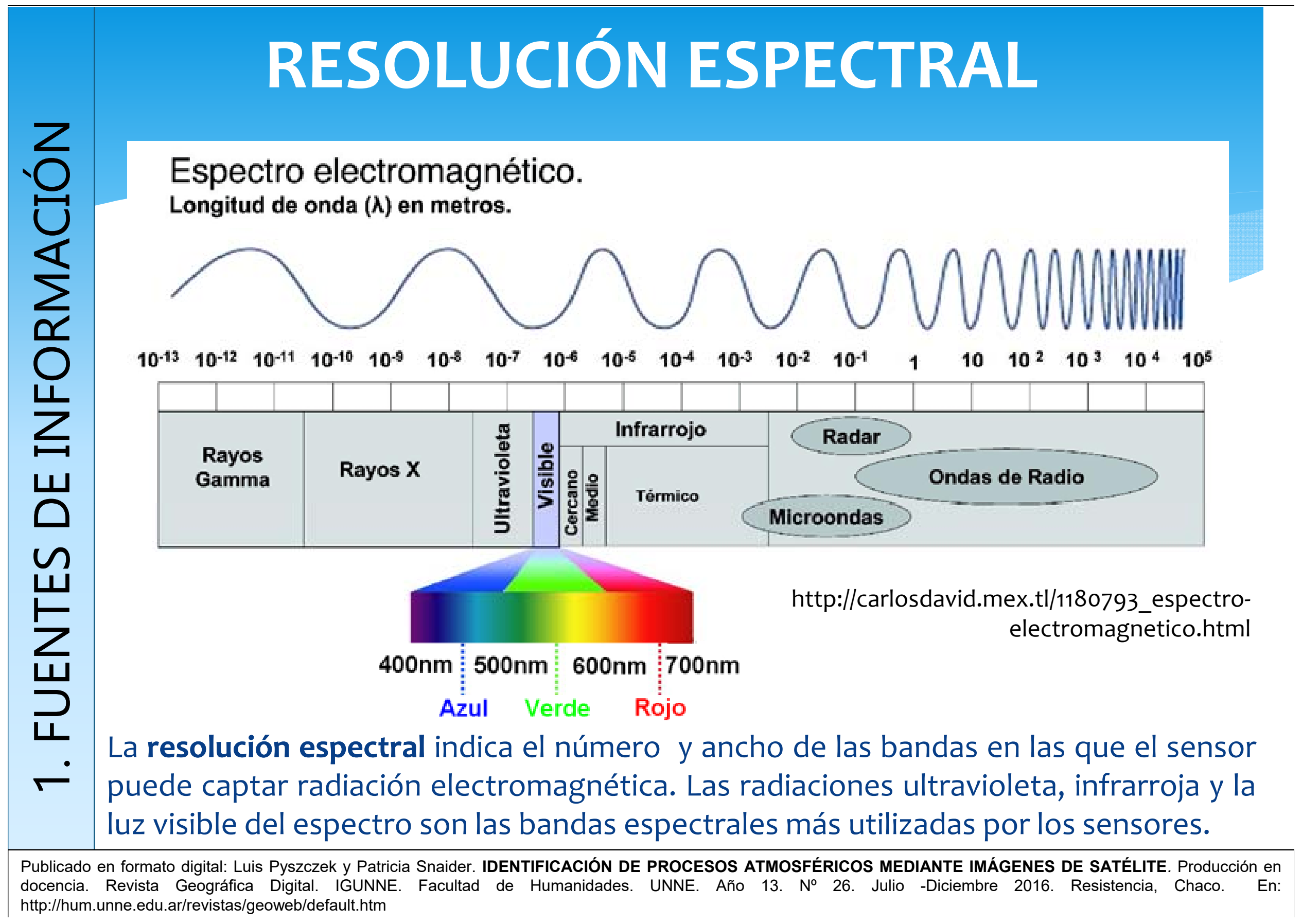




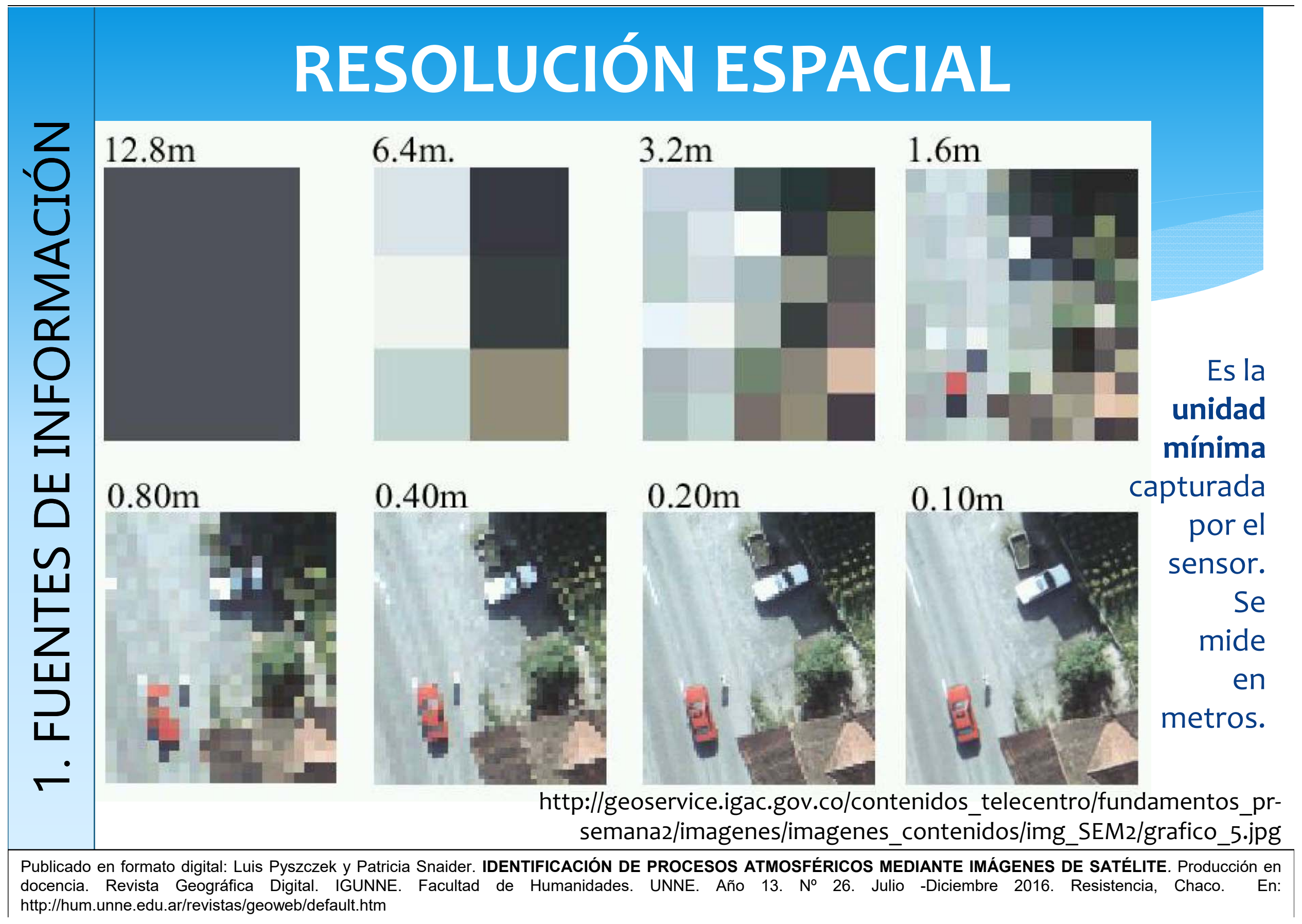




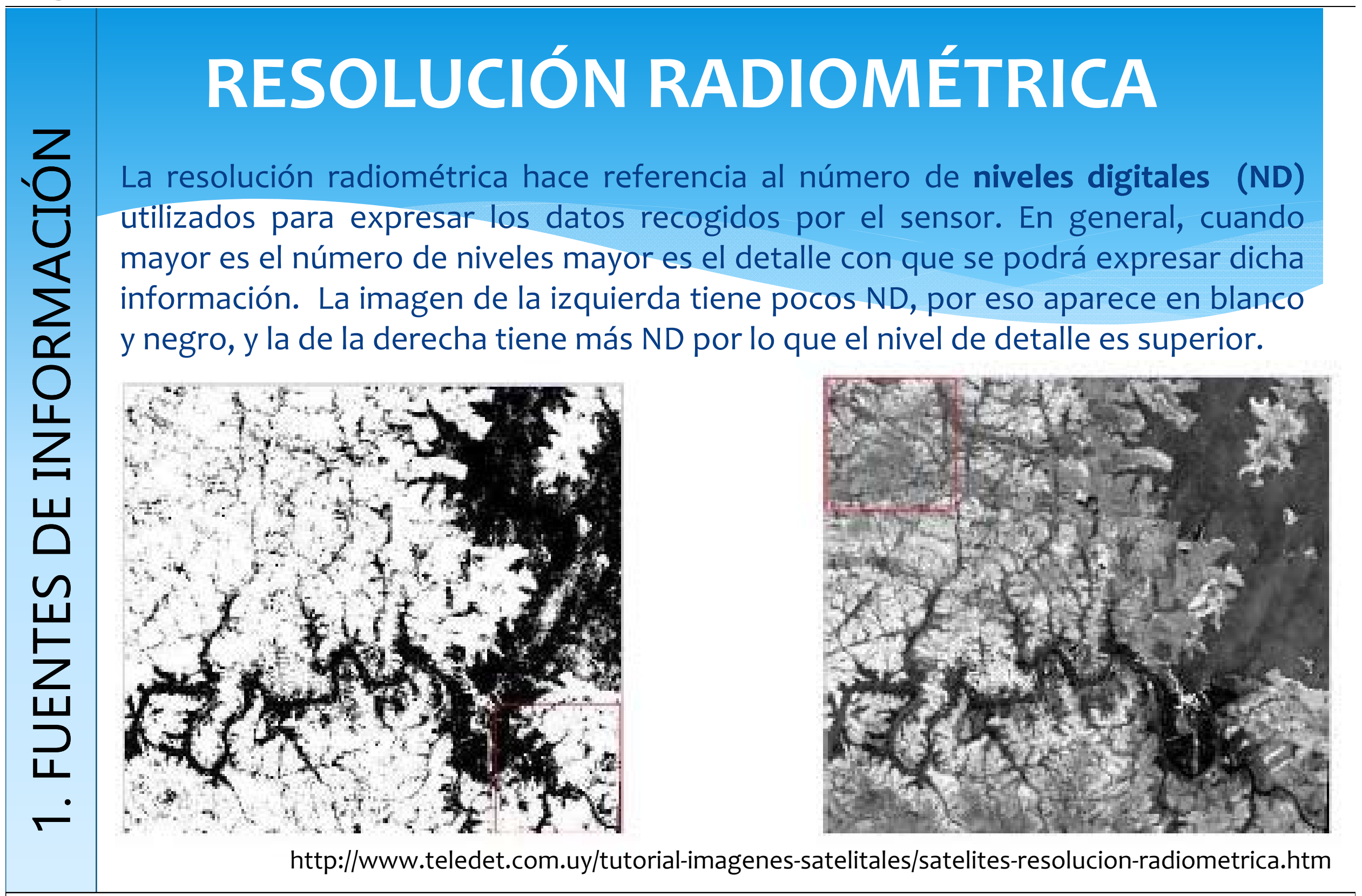

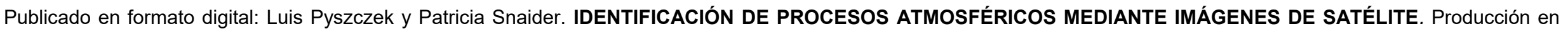

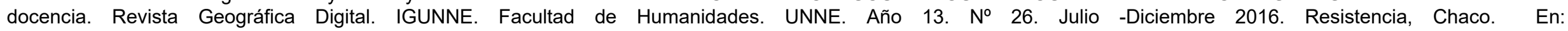
http://hum.unne.edu.ar/revistas/geoweb/default.htm 


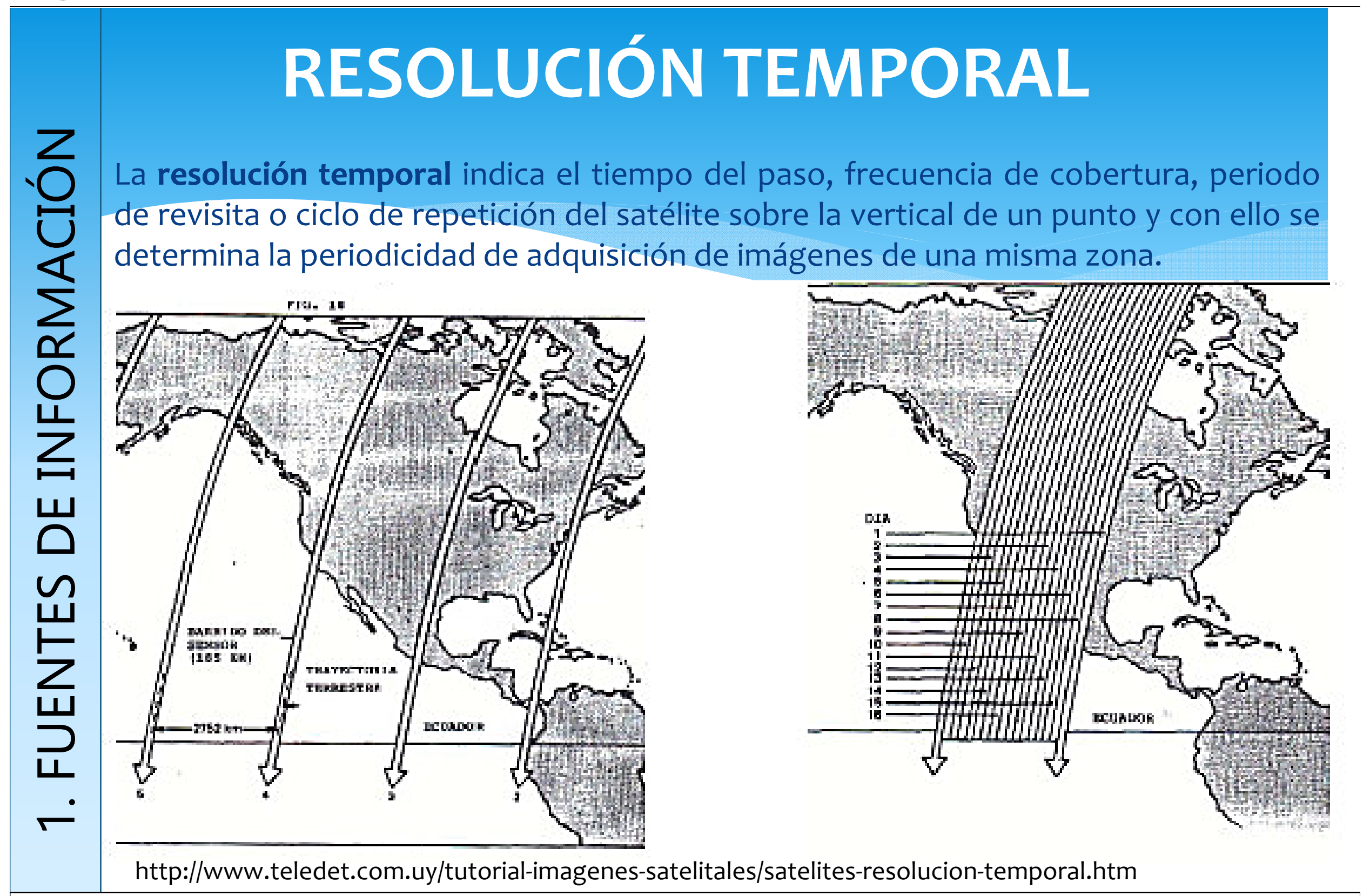

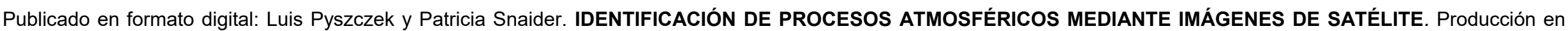

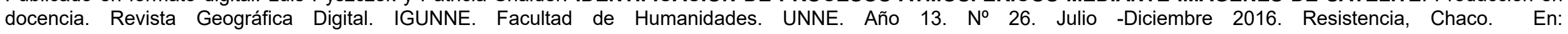
http://hum.unne.edu.ar/revistas/geoweb/default.htm 


\section{RADAR}

El radar (detección y medición [de distancias] por radio) es un sistema que usa ondas electromagnéticas para medir distancias, altitudes, direcciones y velocidades de objetos estáticos o móviles como aeronaves, barcos, vehículos motorizados, formaciones meteorológicas y el propio terreno. Su funcionamiento se basa en emitir un impulso de radio, que se refleja en el objetivo y se recibe típicamente en la misma posición del emisor (CONAGUA, 2015).

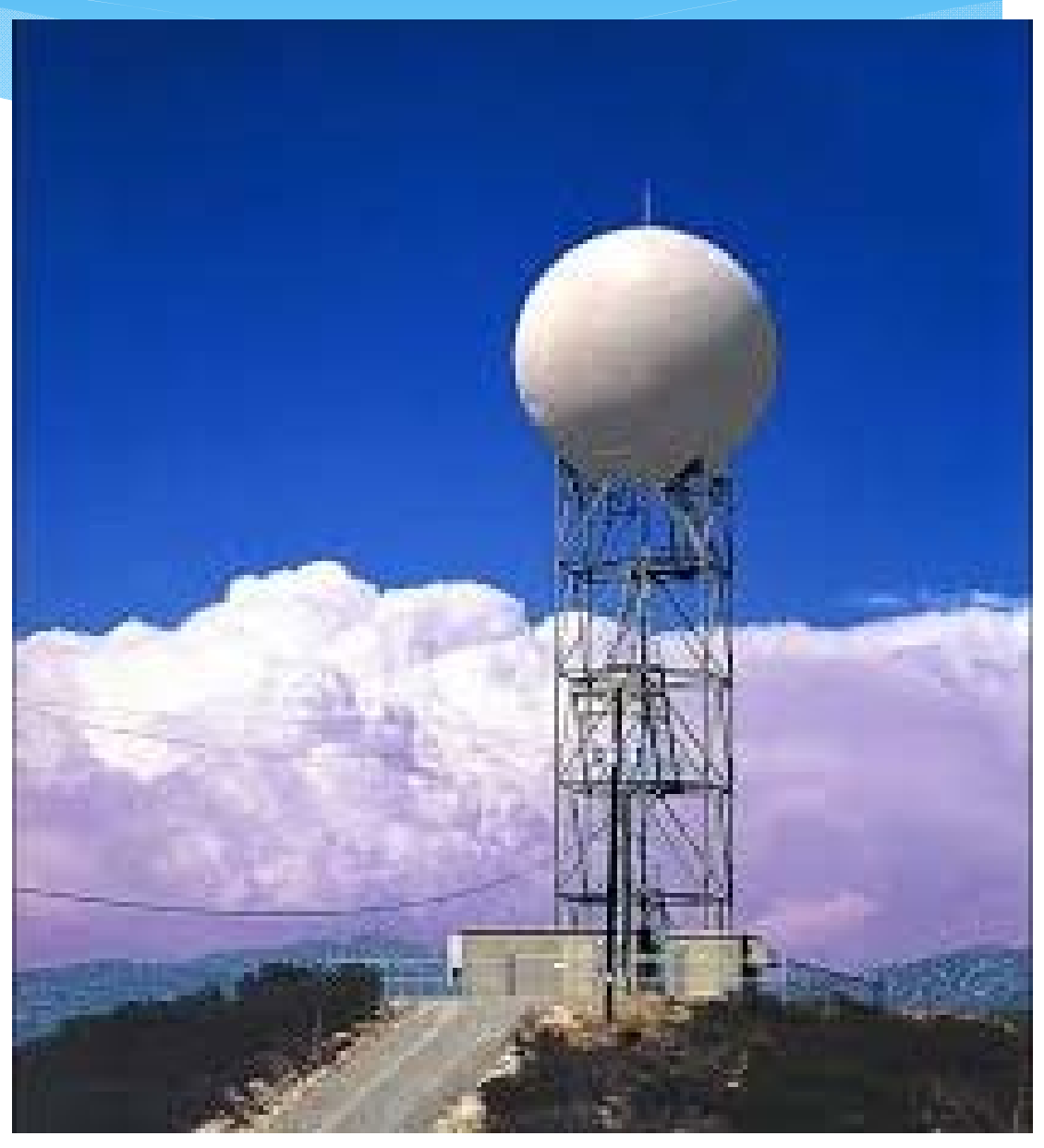

Publicado en formato digital: Luis Pyszczek y Patricia Snaider. IDENTIFICACIÓN DE PROCESOS ATMOSFÉRICOS MEDIANTE IMÁGENES DE SATÉLITE. Producción en docencia. Revista Geográfica Digital. IGUNNE. Facultad de Humanidades. UNNE. Año 13. № 26. Julio -Diciembre 2016. Resistencia, Chaco. En: http://hum.unne.edu.ar/revistas/geoweb/default.htm 


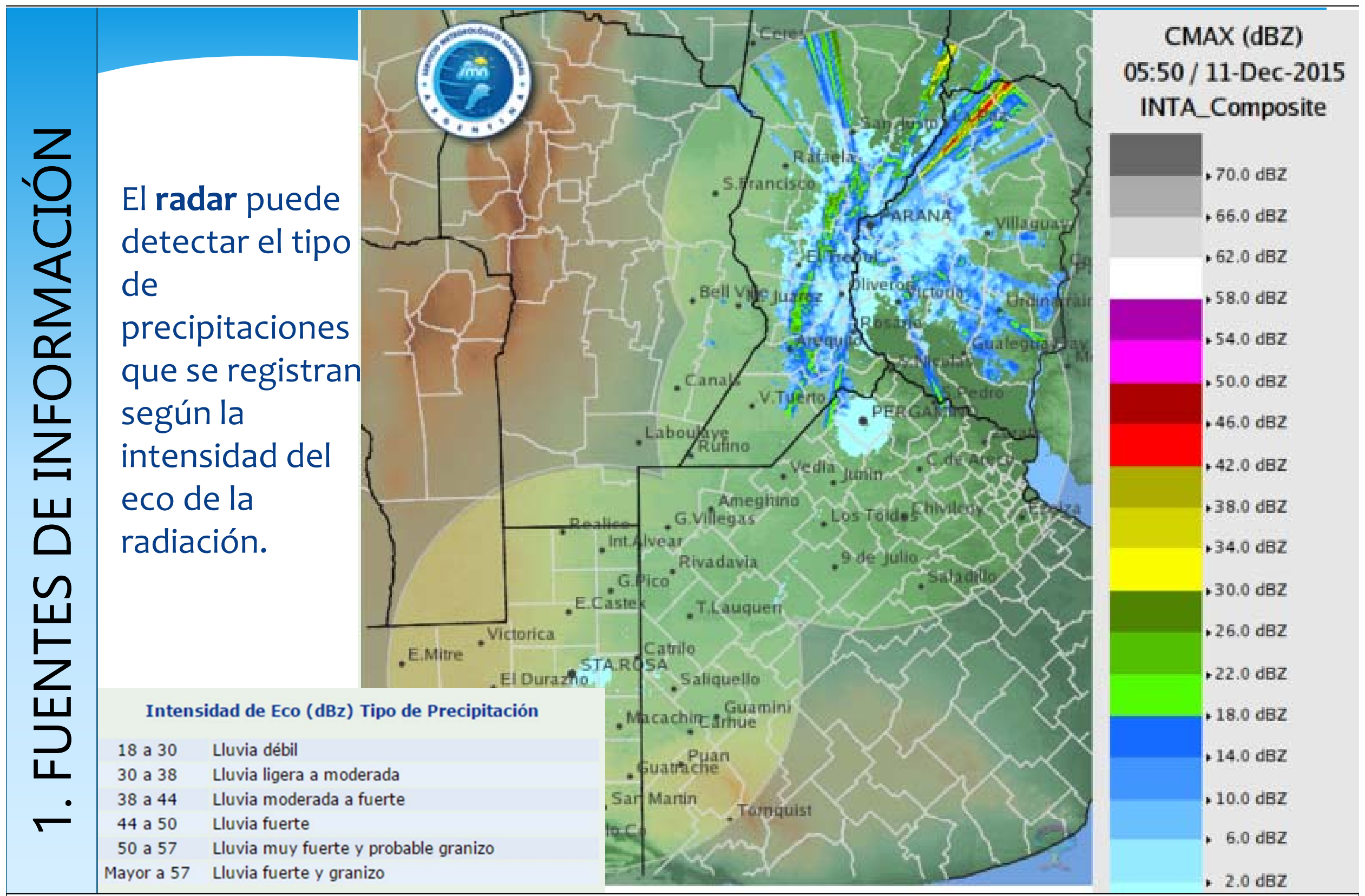

Publicado en formato digital: Luis Pyszczek y Patricia Snaider. IDENTIFICACIÓN DE PROCESOS ATMOSFÉRICOS MEDIANTE IMÁGENES DE SATÉLITE. Producción en docencia. Revista Geográfica Digital. IGUNNE. Facultad de Humanidades. UNNE. Año 13. No 26. Julio -Diciembre 2016. http://hum.unne.edu.ar/revistas/geoweb/default.htm 


\section{SERVICIO METEOROLÓGICO NACIONAL}

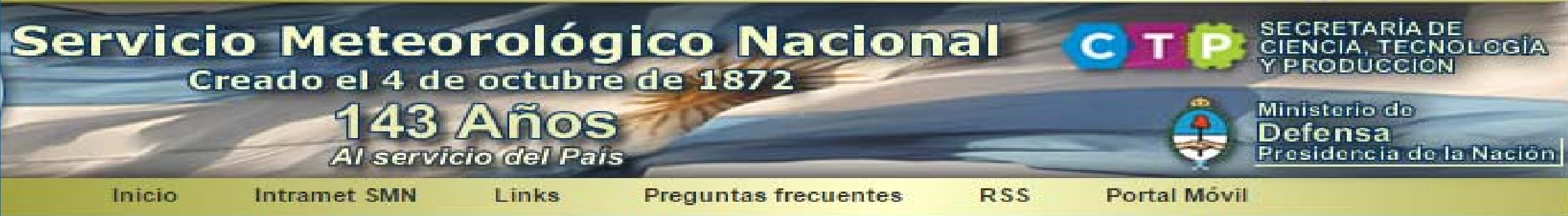

ta ciudad como la página de inicio de este sitio. Aceptar

y Estado del Tiempo para la República Argentina

del Sistema de Alertas sobre Olas de Calor y Salud para:

fónoma de Buenos Aires y Alrededores VERDE

alrededores VERDE

el país

CO DE OTRAS CIUDADES

Estado del Tiempo
El sitio web del SMN (www.smn.gov.ar) donde se pueden encontrar los productos derivados de los satélites...

la Provincia para ver últin

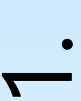

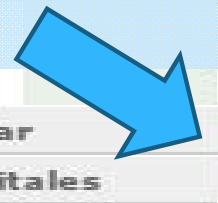

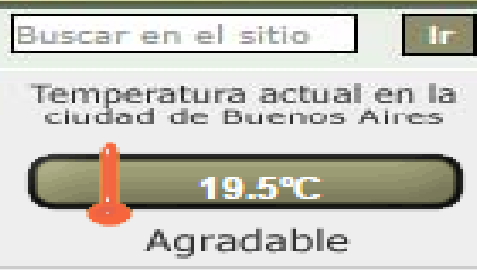

Perspectiva Semanal INFORME PERSPECTIVA SEMANAL

Servicios Climáticos SERVICIOS CLIMÁtICOS Pronóstico climático trimestral para Argentina Pronóstico climático trimestral para la cuenca del Plata - Nuevo-

\section{Observaciones} INDICE UV - CABA:

$\mathbf{O}$

« Estado del Tiempo

* Centro de Meteorología por

Sensores Remotos

Publicado en formato digital: Luis Pyszczek y Patricia Snaider. IDENTIFICACIÓN DE PROCESOS ATMOSFÉRICOS MEDIANTE IMÁGENES DE SATÉLITE. Producción en docencia. Revista Geográfica Digital. IGUNNE. Facultad de Humanidades. UNNE. Año 13. No 26. Julio -Diciembre 2016. http://hum.unne.edu.ar/revistas/geoweb/default.htm 


\section{SATÉLITE UTILIZADO POR EL SMN}

El GOES 13 (conocido como GOES-N antes de entrar en funcionamiento) es un satélite meteorológico estadounidense que forma parte de la Administración Nacional Oceánica de Estados Unidos y el sistema Operational Environmental Satellite geoestacionario de la Atmósfera.

El 14 de abril de 2010, GOES-13 se convirtió en el satélite meteorológico operativo para GOES-ESTE. Después de pasar brevemente desconectado debido a una colisión de micrometeoroides, el 22 de mayo de 2013, nuevamente estuvo en línea y totalmente funcional a partir del 10 de junio 2013. Es el que proporciona las imágenes meteorológicas para Argentina y Sudamérica.

\section{goes-13 2016/11/12 11:45:28 Shr - Argentina}

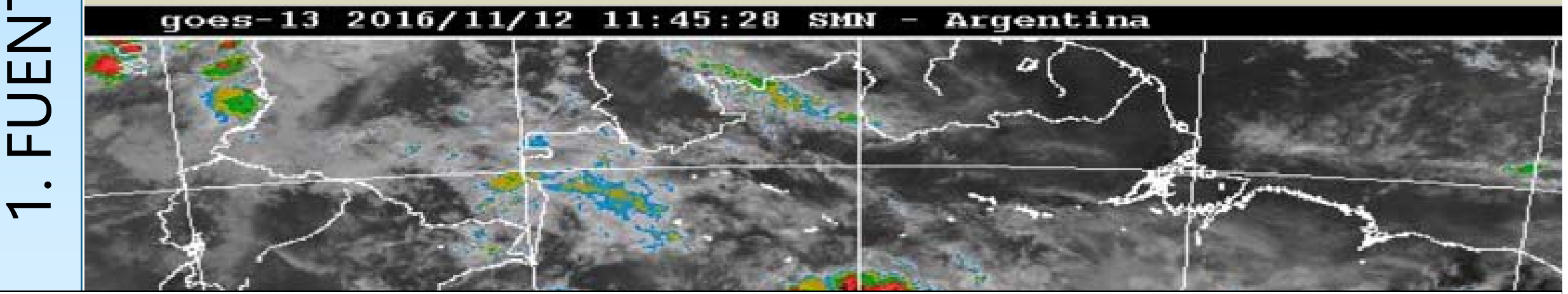

Publicado en formato digital: Luis Pyszczek y Patricia Snaider. IDENTIFICACIÓN DE PROCESOS ATMOSFÉRICOS MEDIANTE IMÁGENES DE SATÉLITE. Producción en docencia. Revista Geográfica Digital. IGUNNE. Facultad de Humanidades. UNNE. Año 13. No 26. Julio -Diciembre 2016. Resistencia, Chaco. En: http://hum.unne.edu.ar/revistas/geoweb/default.htm 


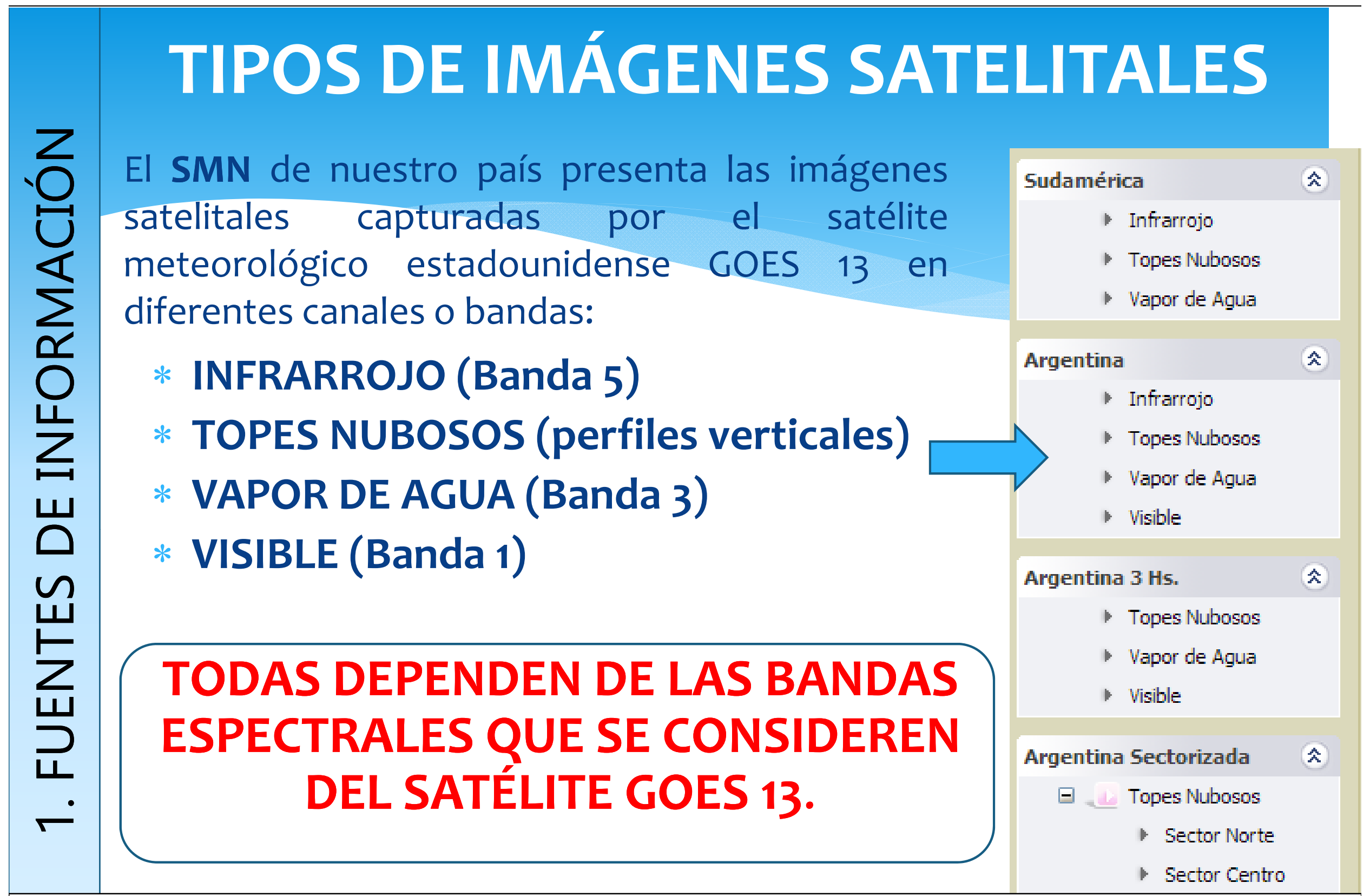

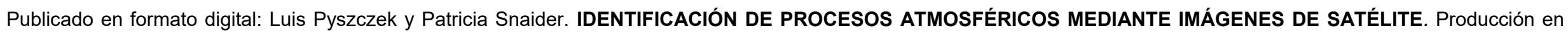

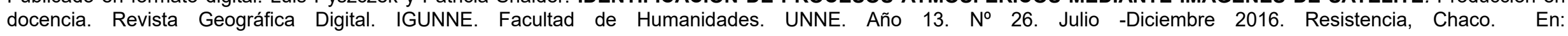
http://hum.unne.edu.ar/revistas/geoweb/default.htmc 


\section{TIPOS DE IMÁGENES SATELITALES}

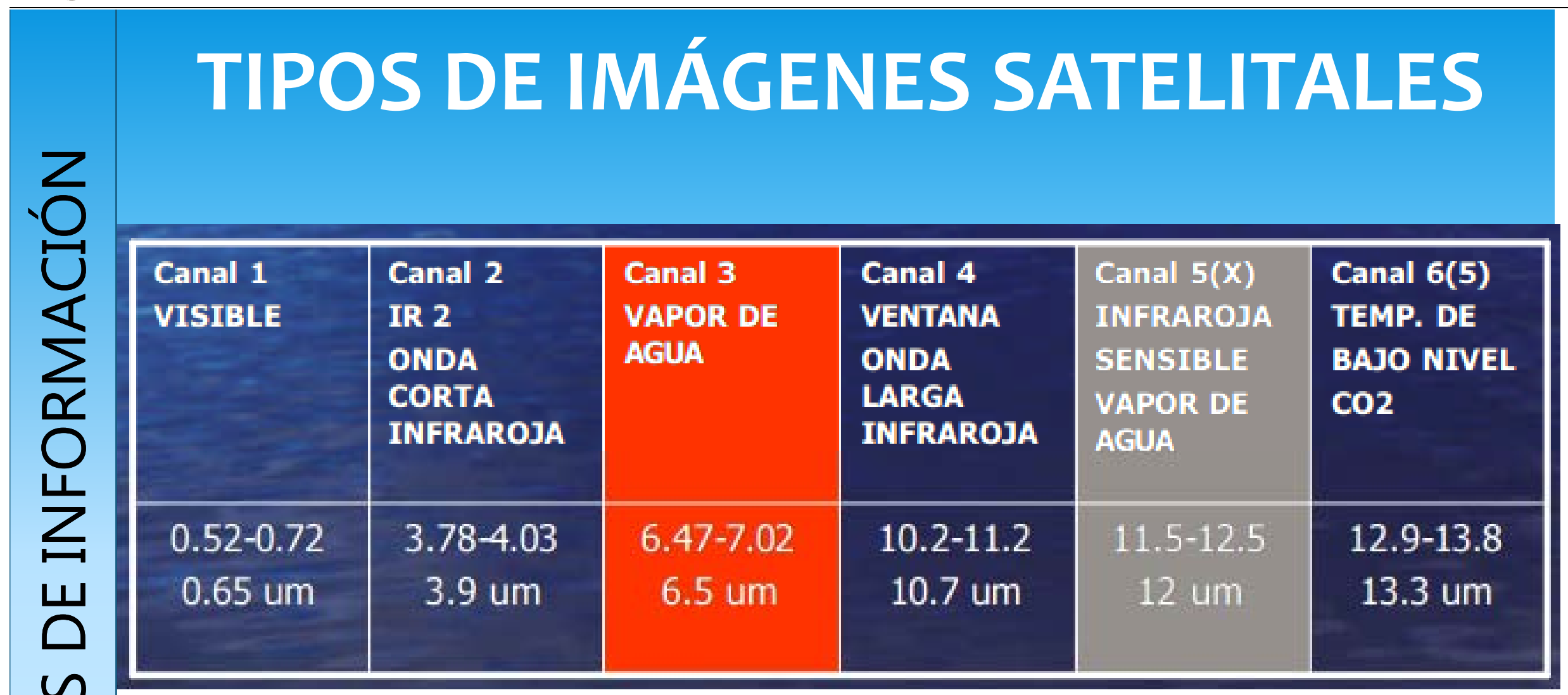

El Satélite geoestacionario GOES tiene dos funciones principales: como Imagen y como Sondaje.

Como imagen recoge la radianza atmosférica y terrestre en diferentes canales; Visible, Infrarroja y Vapor de Agua.

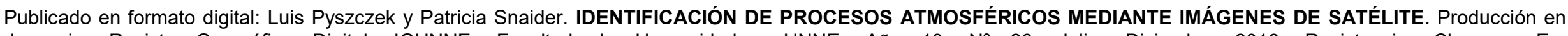

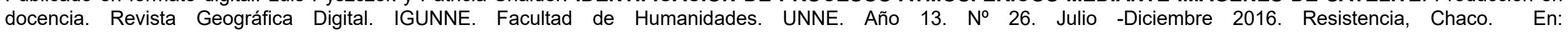
http://hum.unne.edu.ar/revistas/geoweb/default.htm 


\begin{tabular}{|c|c|c|}
\hline & CANAL & CARACTERÍSTICA \\
\hline & Canal 1 VISIBLE & $\begin{array}{l}\text { Útil para el análisis de Nubosidad, contaminación, detección de } \\
\text { humos y tormentas. Resolución de } 1 \mathrm{Km} \text {. }\end{array}$ \\
\hline & Canal 2 (Banda 2) & $\begin{array}{l}\text { Útil para identificar niebla en la noche. Permite diferenciar } \\
\text { nubes de agua, hielo, nieve durante el día Y Temp. Sup. Del mar } \\
\text { (TSM) durante el día. Resolución } 4 \mathrm{Km} \text {. }\end{array}$ \\
\hline & Canal 3 (Banda 3) & $\begin{array}{l}\text { Identifica contenido y advección de humedad en los niveles } \\
\text { medios de la atmósfera y movimientos atmosféricos en los } \\
\text { niveles medios/ altos de la atmósfera. }\end{array}$ \\
\hline & Canal 4 (Banda 4) & $\begin{array}{l}\text { Identifica nubosidad y movimiento en la atmósfera. } \\
\text { Identificación de tormentas severas y lluvias intensas. }\end{array}$ \\
\hline$\frac{\sum_{\square}}{\square}$ & Canal 5 (Banda 5) & $\begin{array}{l}\text { Útil para la identificación de humedad de bajo nivel, } \\
\text { determinación de la TSM y detección del polvo y ceniza } \\
\text { volcánica. Resolución de } 4 \mathrm{Km} \text {. }\end{array}$ \\
\hline$\leftarrow$ & Canal 6 & $\begin{array}{l}\text { Útil para determinar las características de las nubes. Como } \\
\text { presión en el tope de la nube. Resolución de } 8 \mathrm{Km} \text {. }\end{array}$ \\
\hline
\end{tabular}

Publicado en formato digital: Luis Pyszczek y Patricia Snaider. IDENTIFICACIÓN DE PROCESOS ATMOSFÉRICOS MEDIANTE IMÁGENES DE SATÉLITE. Producción en docencia. Revista Geográfica Digital. IGUNNE. Facultad de Humanidades. UNNE. Año 13. No 26. Julio -Diciembre 2016. Resistencia, Chaco. En: http://hum.unne.edu.ar/revistas/geoweb/default.htm 


\section{PALABRAS CLAVES...}

Órbita: curva que describe un cuerpo alrededor de otro en el espacio (planeta, cometa, satélite etc.) como consecuencia de la acción de la fuerza de gravedad. Trayectoria completa y estable que realizan los satélites artificiales alrededor de la Tierra.

Órbita Geoestacionaria: una órbita geoestacionaria O GEO es una órbita geosíncrona en el plano ecuatorial terrestre, con una excentricidad nula (órbita circular) y un movimiento de Oeste a Este. Desde tierra, un objeto geoestacionario parece inmóvil en el cielo (de gran interés para los operadores de satélites artificiales de comunicación y de televisión).

Geosincrónico: periodo orbital del satélite es igual al periodo de rotación sidéreo de la Tierra, 23 horas, 56 minutos y 4,09 segundos. 


\section{PALABRAS CLAVES...}

Órbita Polar: es una órbita que pasa por encima de los polos de un planeta o muy cerca de ellos, es decir la inclinación de la órbita es cercana a los 90 grados. Un satélite en órbita polar pasa sobre cada punto del planeta cuando éste gira sobre su eje.

Resolución Espectral: la resolución espectral se refiere al número y ancho de las bandas espectrales registradas por un satélite. Cuanto más estrechas sea el rango de estas bandas mayor será la resolución espectral.

Resolución Espacial: se refiere a la finura de detalles visibles en una imagen: cuanto menor es el área terrestre representada por cada píxel en una imagen digital, mayores son los detalles que pueden ser captados y mayor es la resolución espacial. 


\section{PALABRAS CLAVES...}

Resolución Radiométrica: hace referencia al número de niveles digitales utilizados para expresar los datos recogidos por el sensor. En general, cuando mayor es el número de niveles mayor es el detalle con que se podrá expresar dicha información.

Resolución Temporal: es una medida de la frecuencia con la que un satélite es capaz de obtener imágenes de una determinada área. También se denomina intervalo de revisita. Altas resoluciones temporales son importantes en el monitoreo de eventos que cambian en períodos relativamente cortos, como inundaciones, incendios, calidad del agua en el caso de contaminaciones, desarrollo de cosechas, etc. Asimismo, en áreas con cubiertas nubosas casi constantes como por ejemplo las selvas tropicales, las altas resoluciones temporales aumentan la probabilidad de obtener imágenes satisfactorias. 


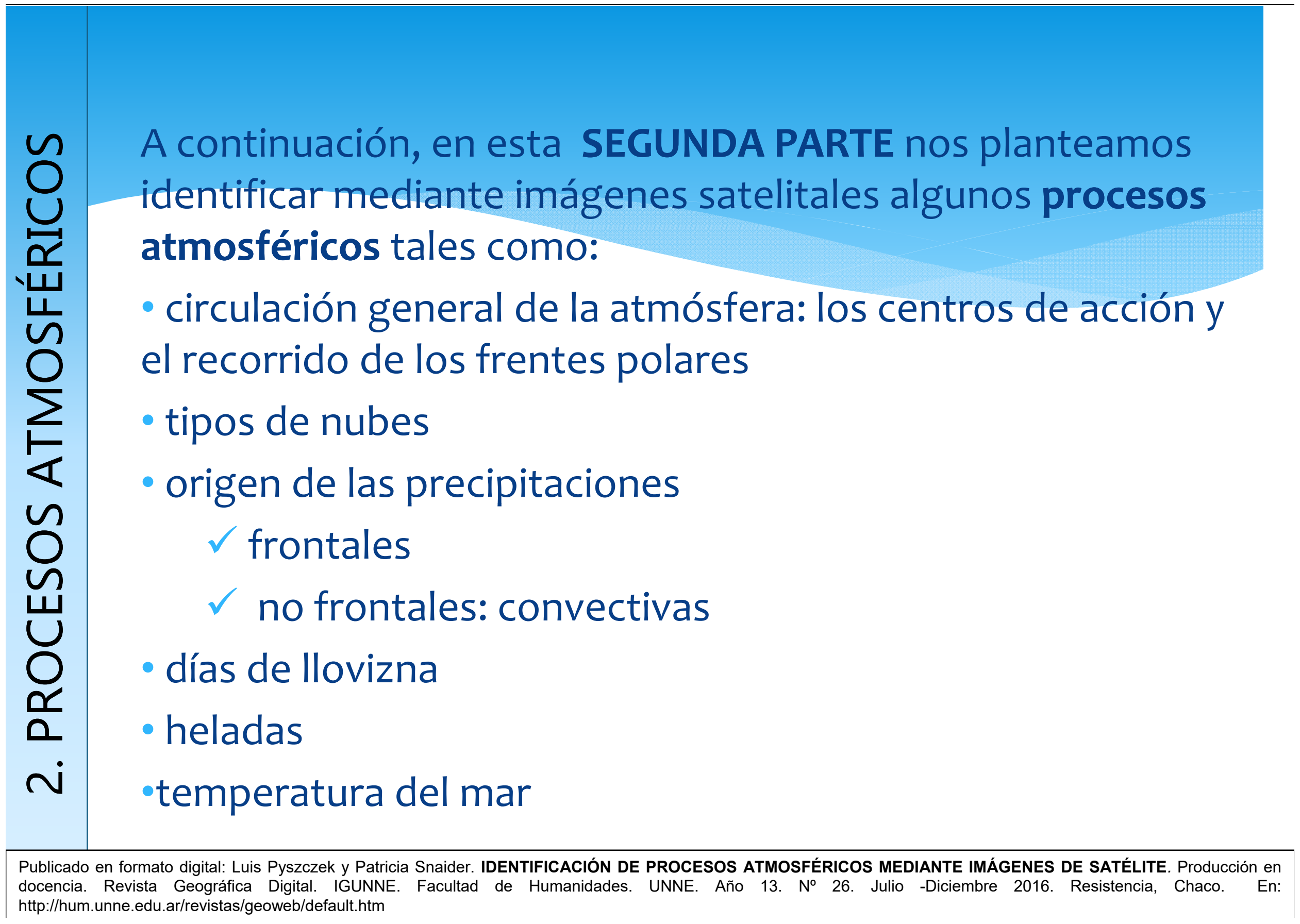




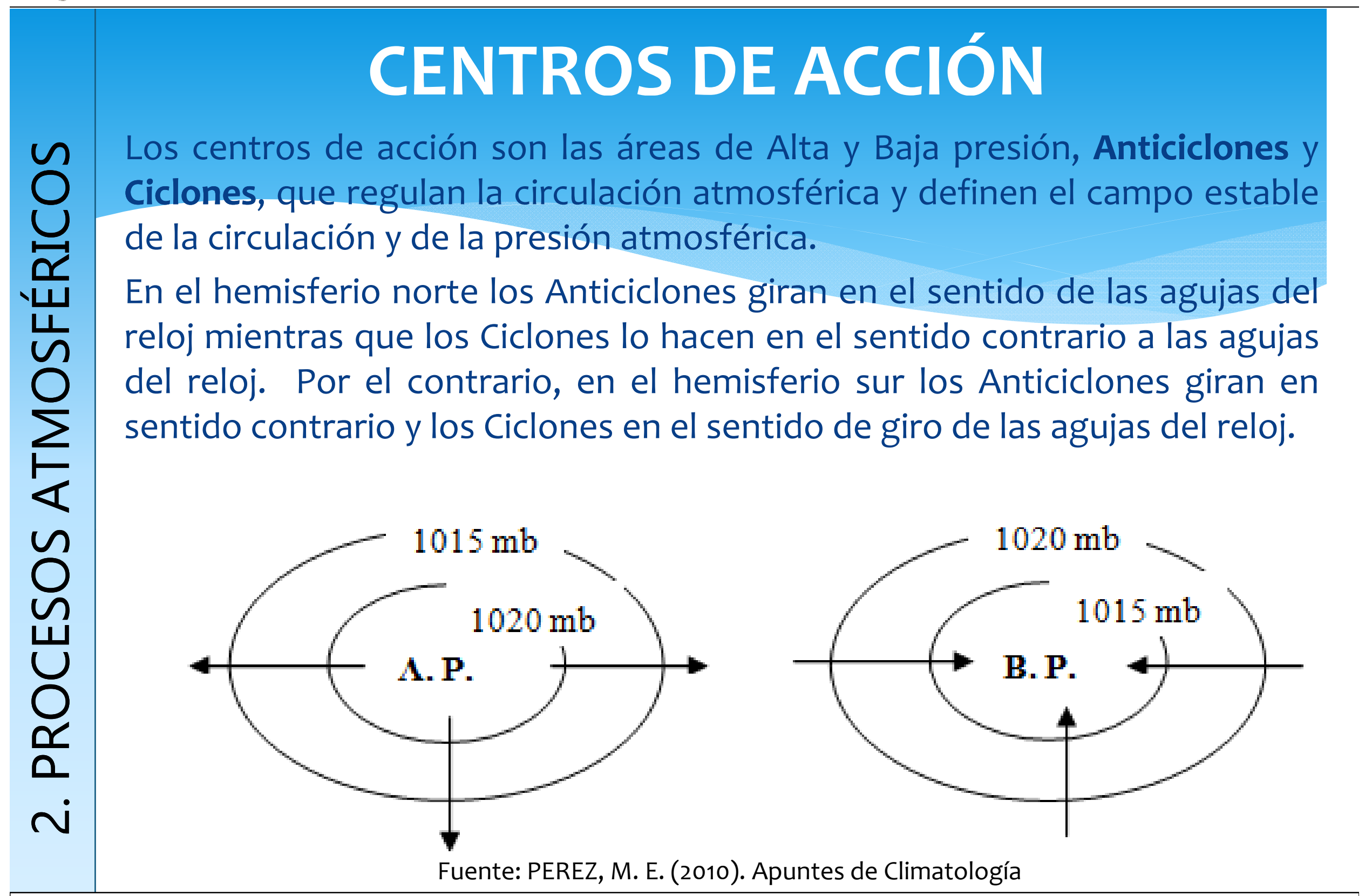

Publicado en formato digital: Luis Pyszczek y Patricia Snaider. IDENTIFICACIÓN DE PROCESOS ATMOSFÉRICOS MEDIANTE IMÁGENES DE SATÉLITE. Producción en docencia. Revista Geográfica Digital. IGUNNE. Facultad de Humanidades. UNNE. Año 13. No 26. Julio -Diciembre 2016. Resistencia, Chaco. En: http://hum.unne.edu.ar/revistas/geoweb/default.htm 


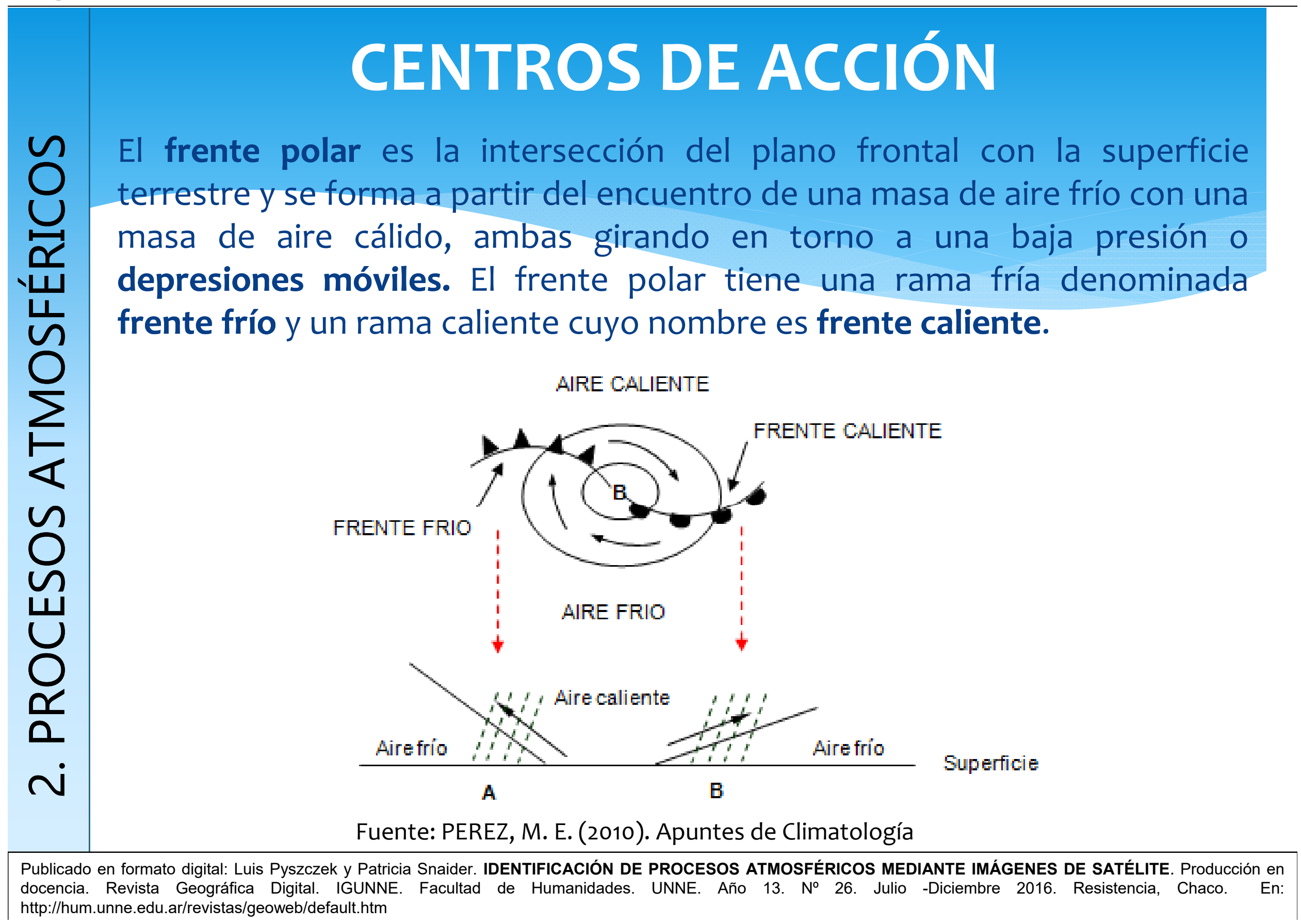


Los Anticiclones semipermanentes se ubican en las áreas polares (Altas Presiones Polares) y hacia los $30^{\circ}$ de latitud en los océanos (Altas Presiones Subtropicales), mientras que los Ciclones Semipermanentes se localizan en el área ecuatorial $\sim$ (Convergencia Intertropical) y hacia los $60^{\circ}$ de latitud (Bajas Presiones Subpolares).

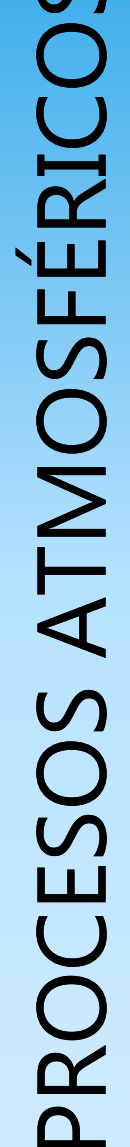

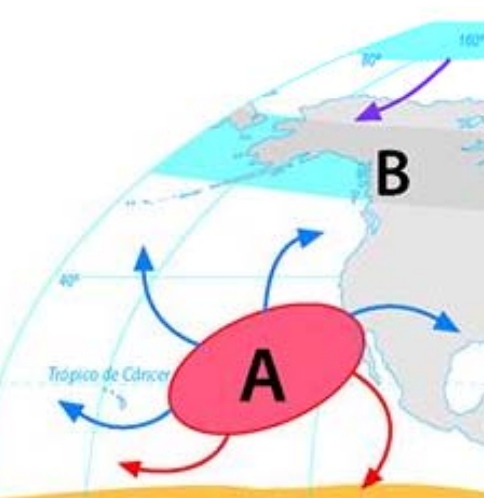

B
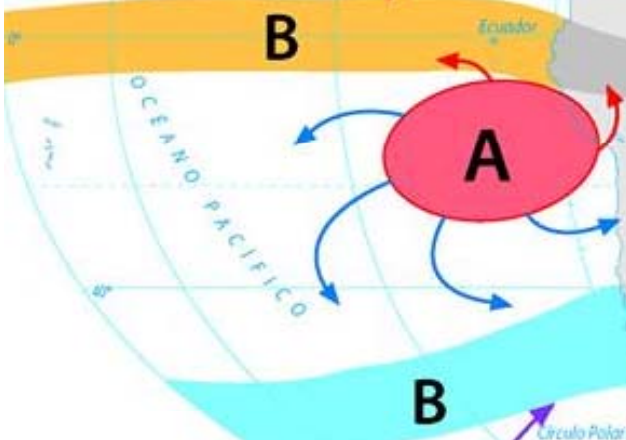
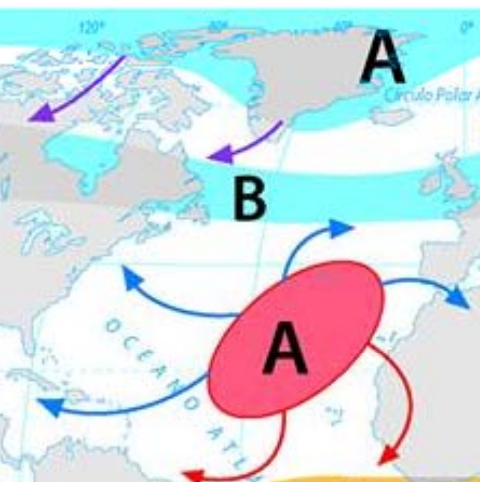

B

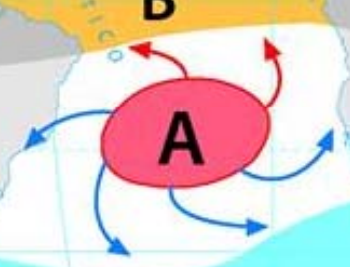

B

A

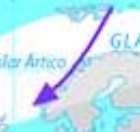

B

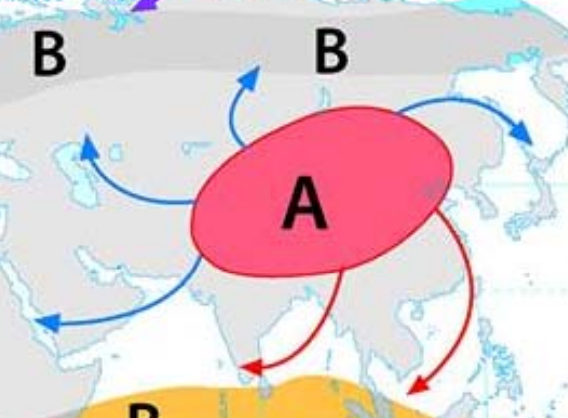

B

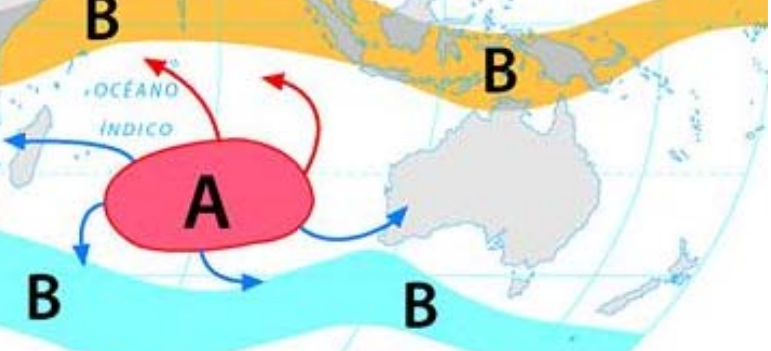

A
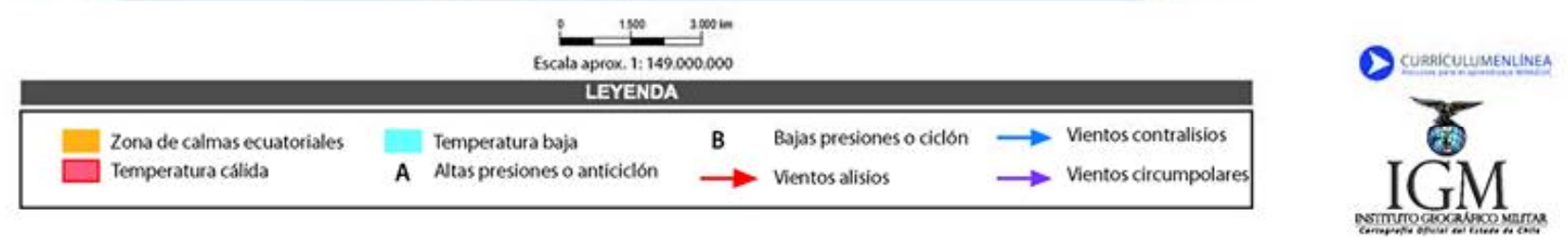

Fuente: KGM, 2011

Publicado en formato digital: Luis Pyszczek y Patricia Snaider. IDENTIFICACIÓN DE PROCESOS ATMOSFÉRICOS MEDIANTE IMÁGENES DE SATÉLITE. Producción en docencia. Revista Geográfica Digital. IGUNNE. Facultad de Humanidades. UNNE. Año 13. No 26. Julio -Diciembre 2016. http://hum.unne.edu.ar/revistas/geoweb/default.htm 


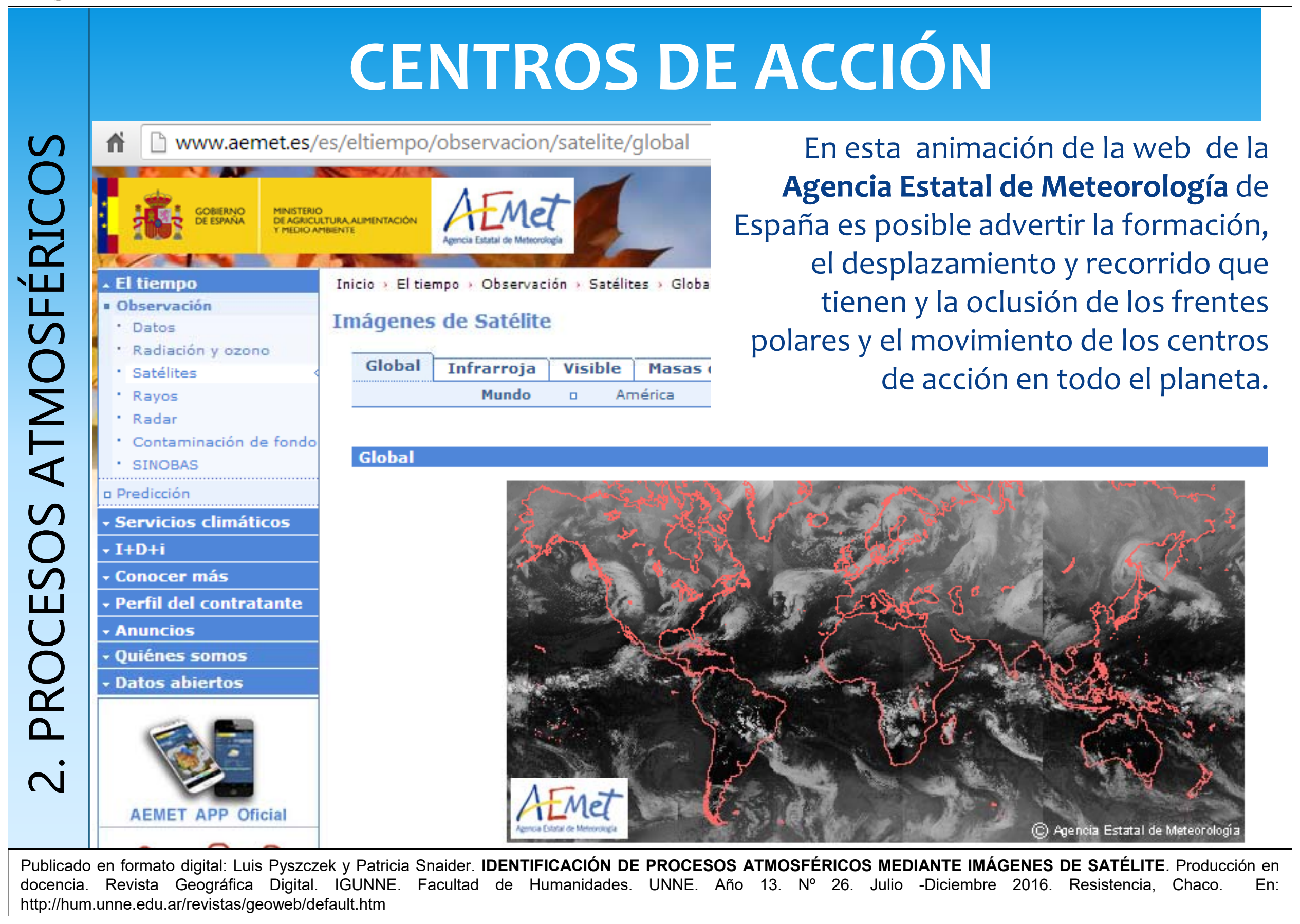




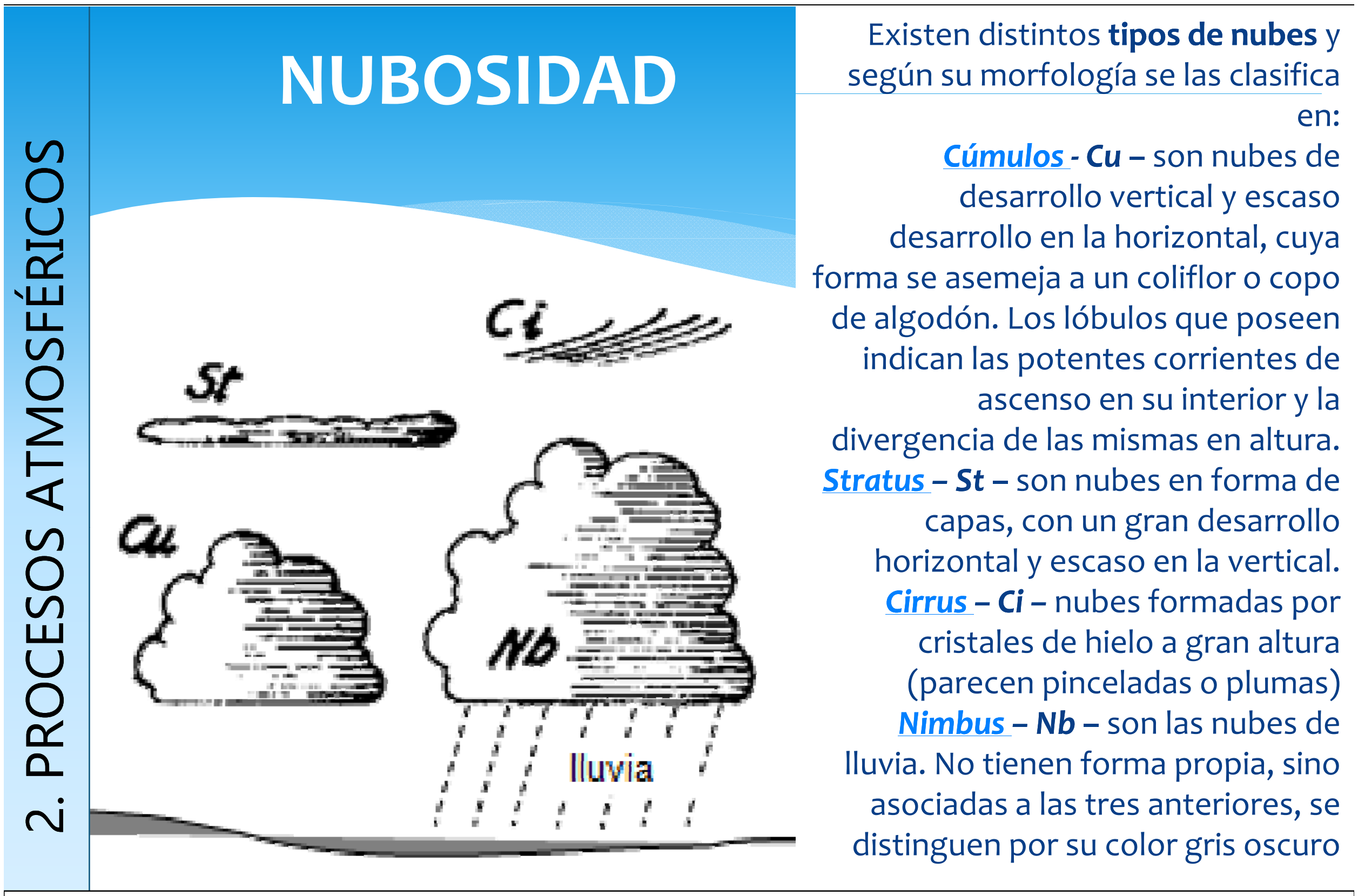

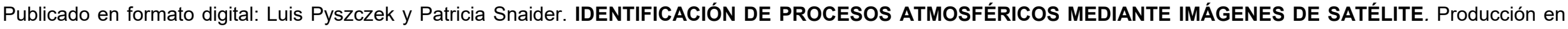

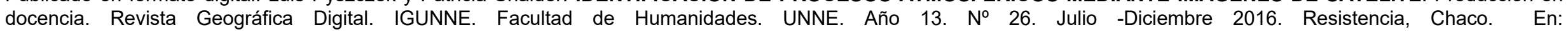
http://hum.unne.edu.ar/revistas/geoweb/default.htm 


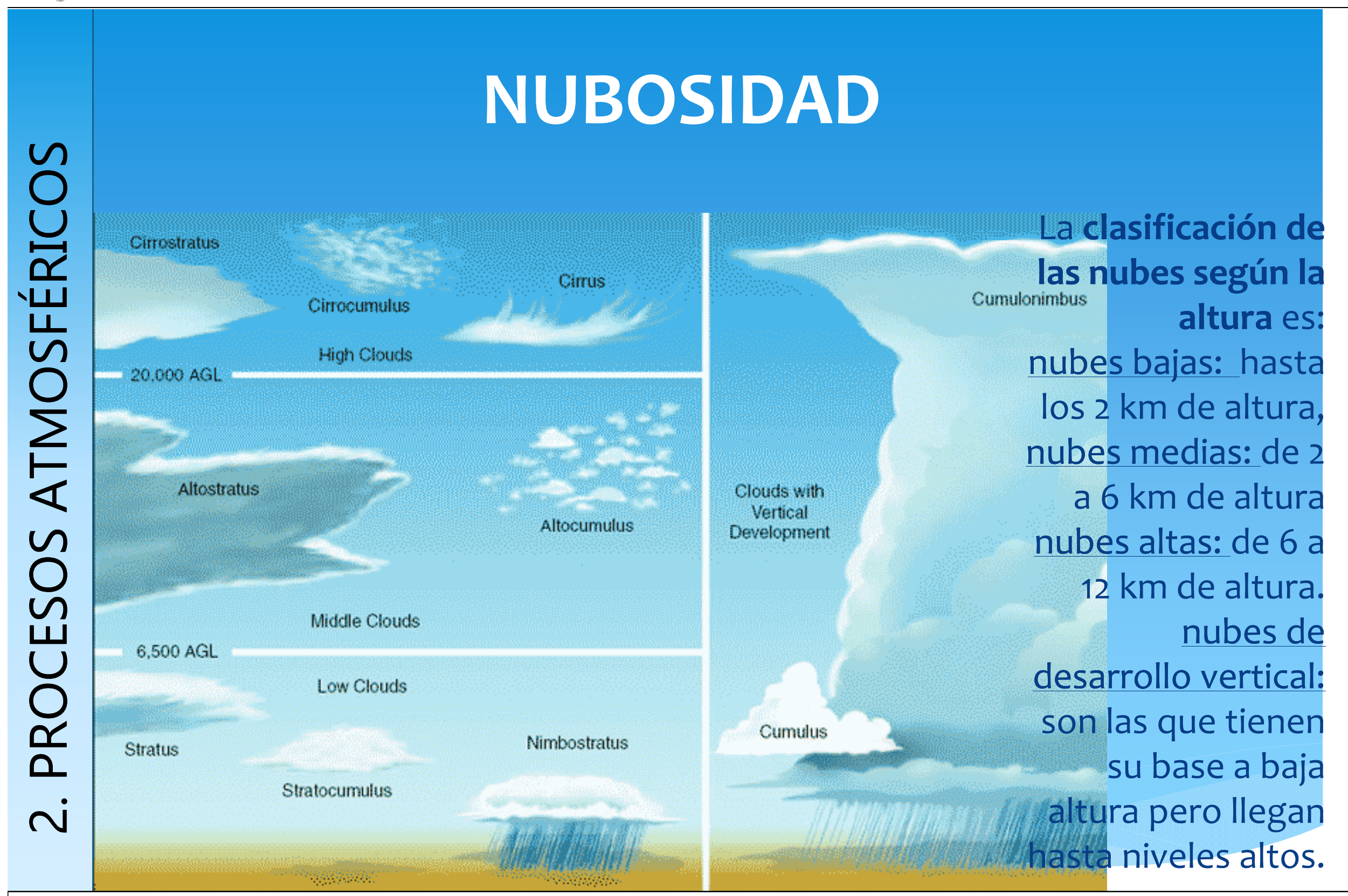

Publicado en formato digital: Luis Pyszczek y Patricia Snaider. IDENTIFICACIÓN DE PROCESOS ATMOSFÉRICOS MEDIANTE IMÁGENES DE SATÉLITE. Producción en docencia. Revista Geográfica Digital. IGUNNE. Facultad de Humanidades. UNNE. Año 13. No 26. Julio -Diciembre 2016. Resistencia, Chaco. En: http://hum.unne.edu.ar/revistas/geoweb/default.htm 
IE Revista Geográfica Digital. IGUNNE. Facultad de Humanidades. UNNE. Año 13. № 26. Julio -Diciembre 2016. ISSN 1668-5180. Resistencia, Chaco

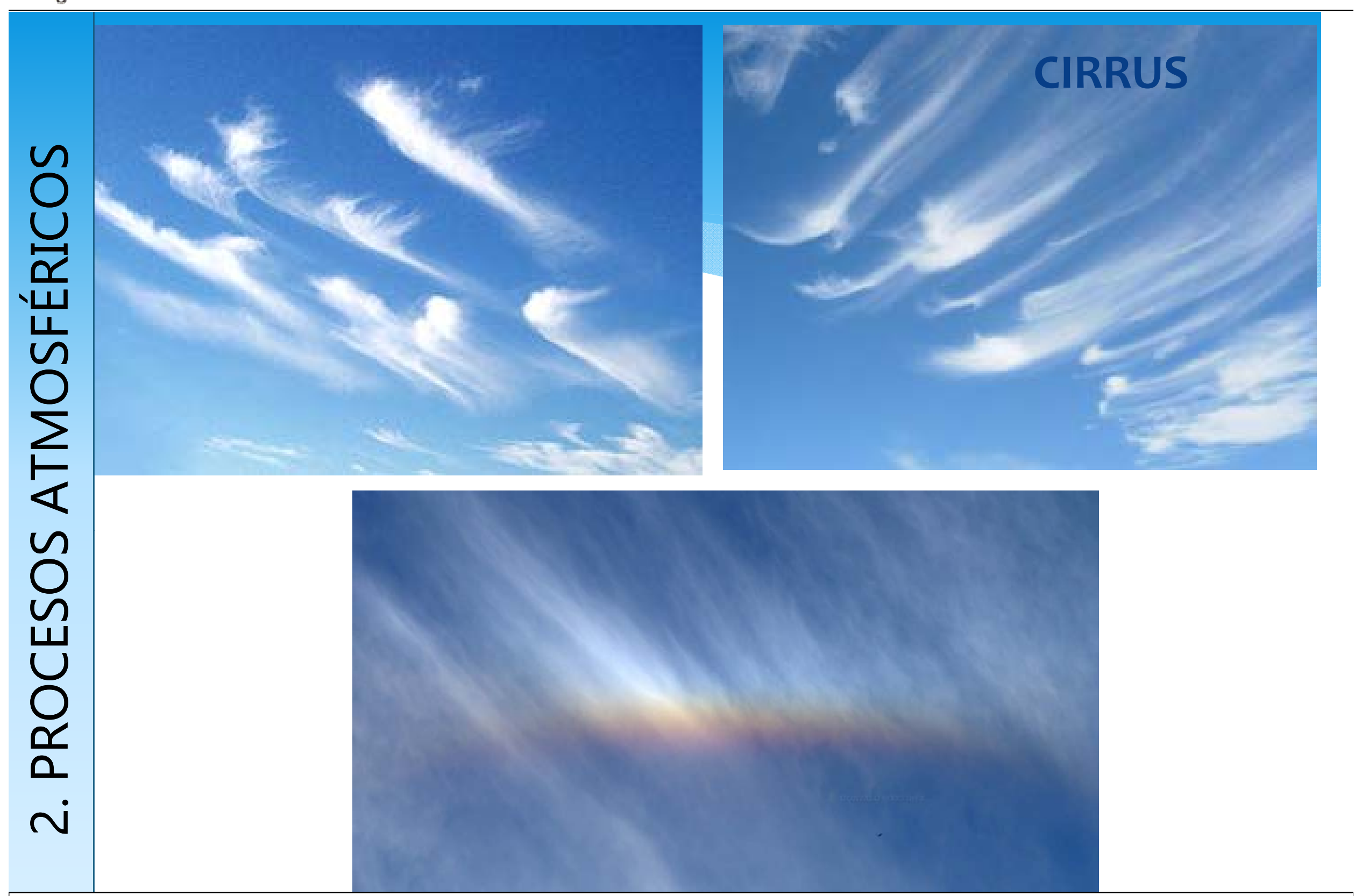

Publicado en formato digital: Luis Pyszczek y Patricia Snaider. IDENTIFICACIÓN DE PROCESOS ATMOSFÉRICOS MEDIANTE IMÁGENES DE SATÉLITE. Producción en docencia. Revista Geográfica Digital. IGUNNE. Facultad de Humanidades. UNNE. Año 13. № 26. Julio -Diciembre 2016. http://hum.unne.edu.ar/revistas/geoweb/default.htm 


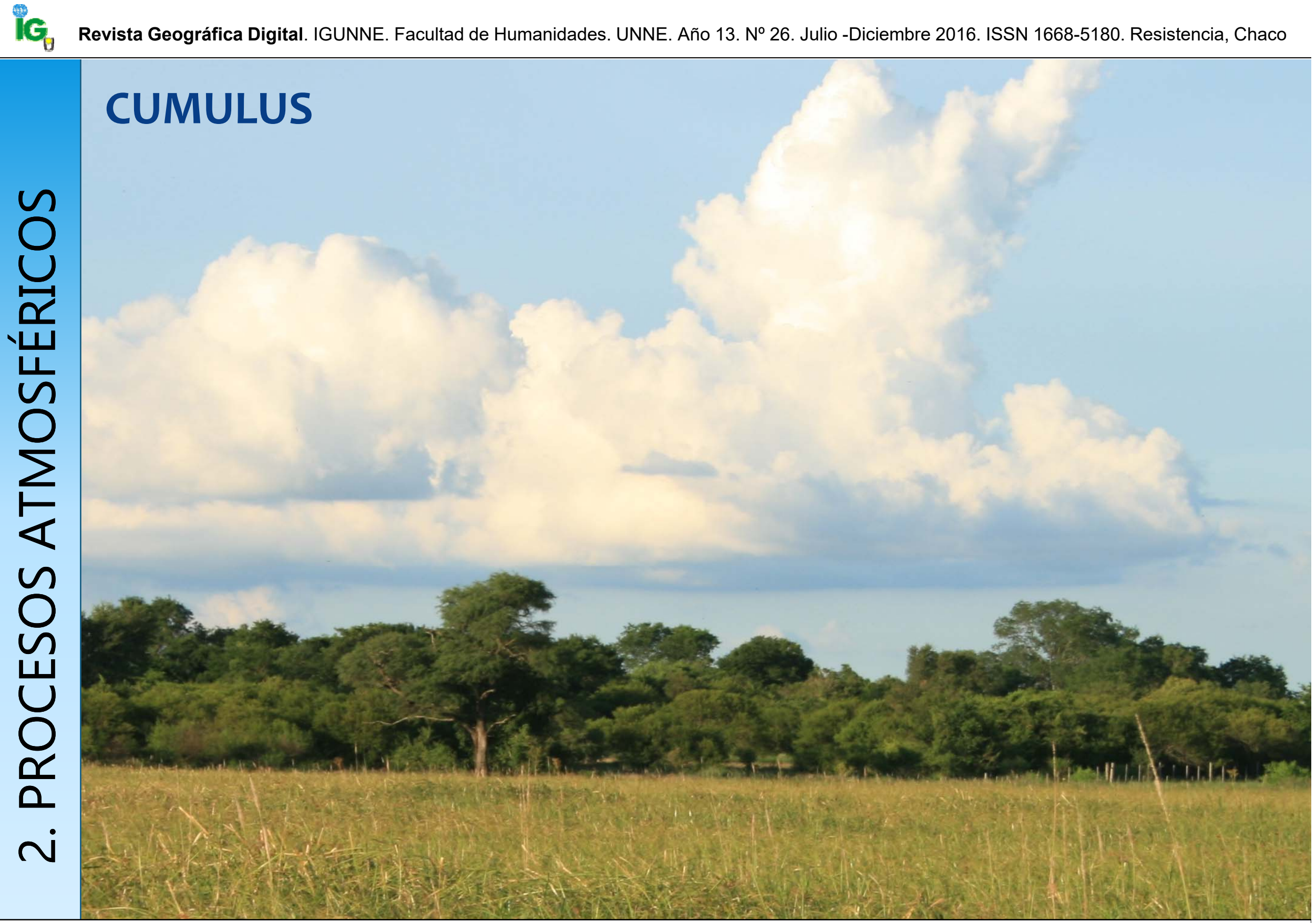

Publicado en formato digital: Luis Pyszczek y Patricia Snaider. IDENTIFICACIÓN DE PROCESOS ATMOSFÉRICOS MEDIANTE IMÁGENES DE SATÉLITE. Producción en docencia. Revista Geográfica Digital. IGUNNE. Facultad de Humanidades. UNNE. Año 13. No 26. Julio -Diciembre 2016. Resistencia, Chaco. En: http://hum.unne.edu.ar/revistas/geoweb/default.htm 


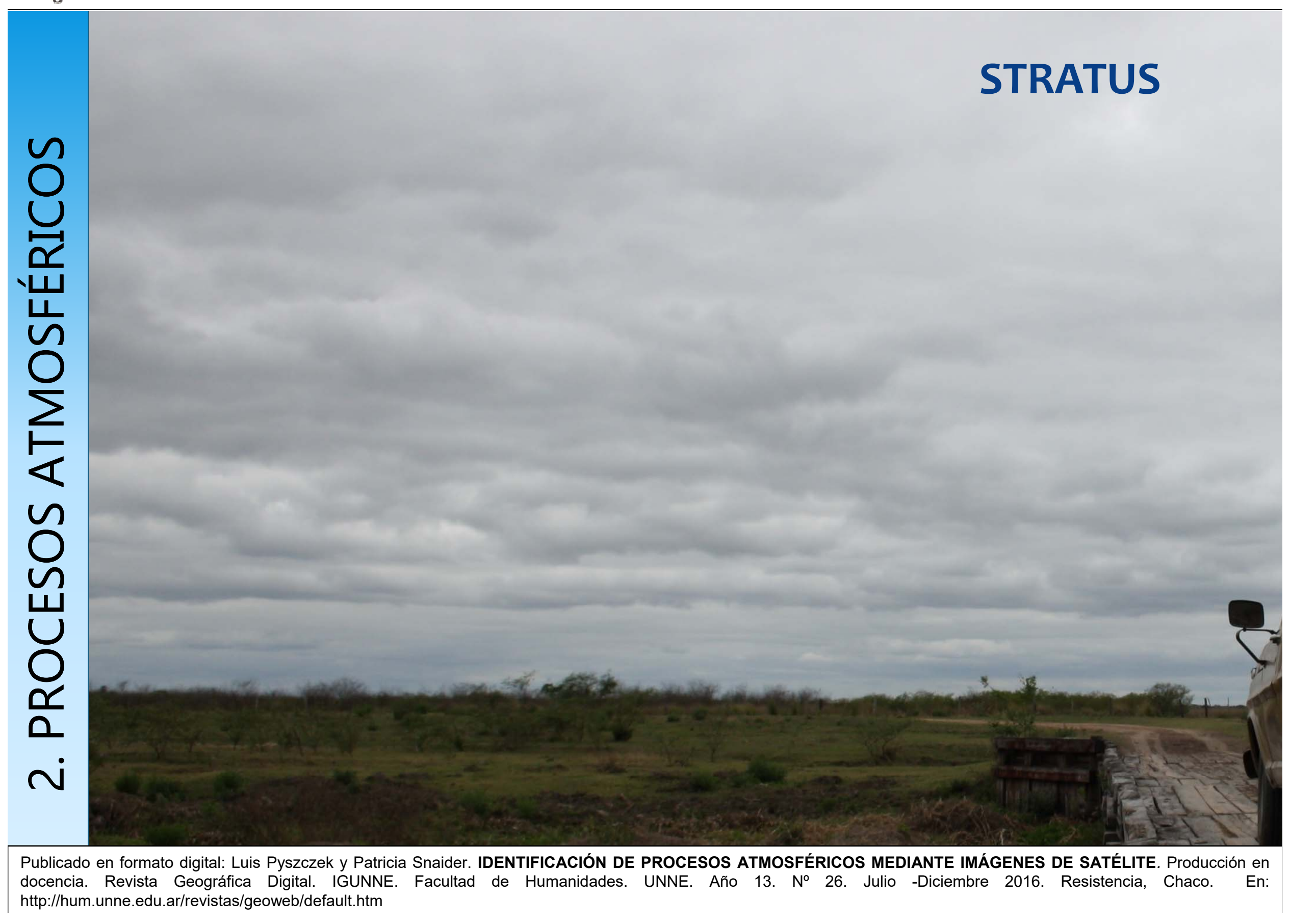




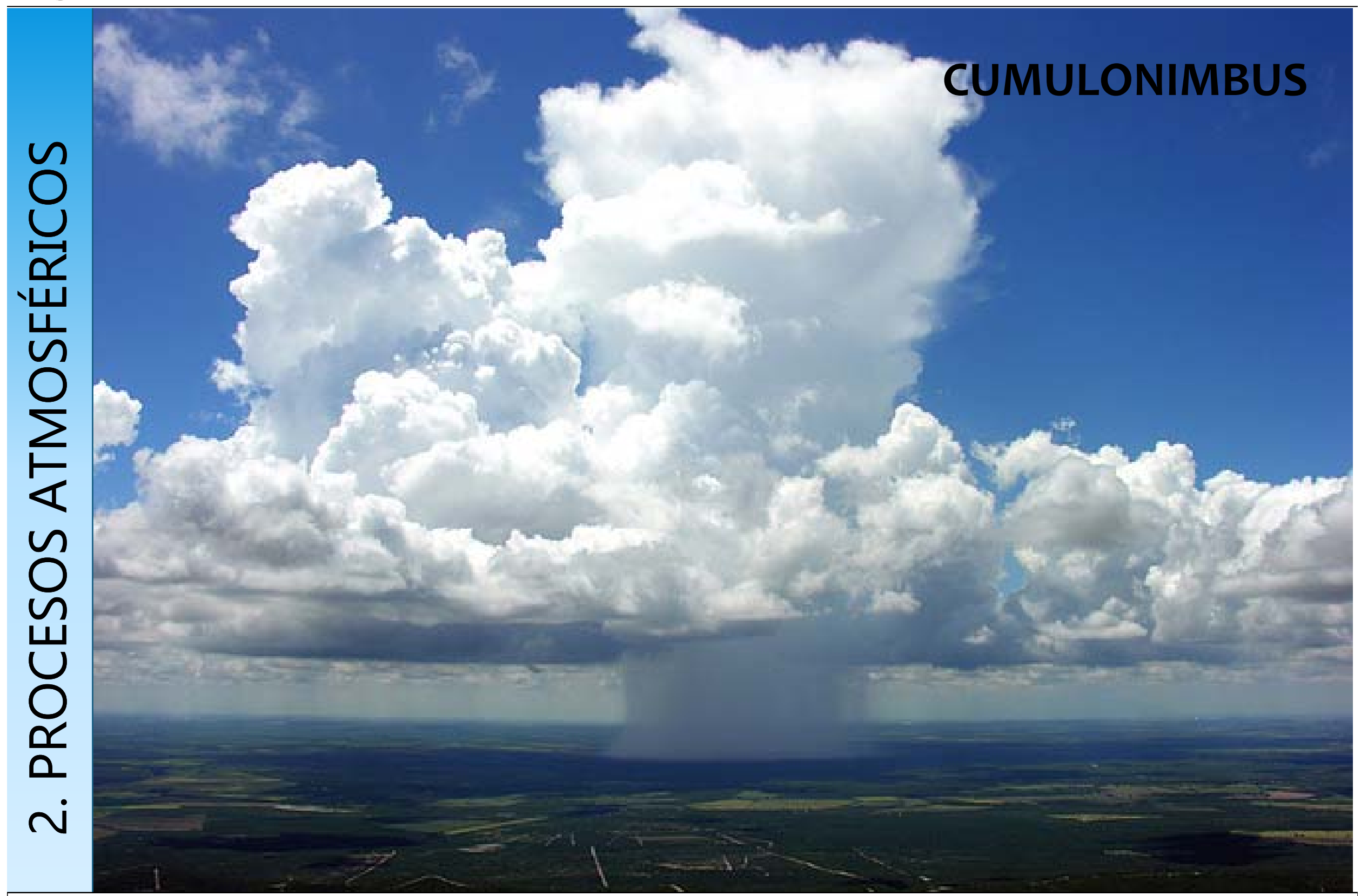

Publicado en formato digital: Luis Pyszczek y Patricia Snaider. IDENTIFICACIÓN DE PROCESOS ATMOSFÉRICOS MEDIANTE IMÁGENES DE SATÉLITE. Producción en docencia. Revista Geográfica Digital. IGUNNE. Facultad de Humanidades. UNNE. Año 13. No 26. Julio -Diciembre 2016. Resistencia, Chaco. En: http://hum.unne.edu.ar/revistas/geoweb/default.htm 


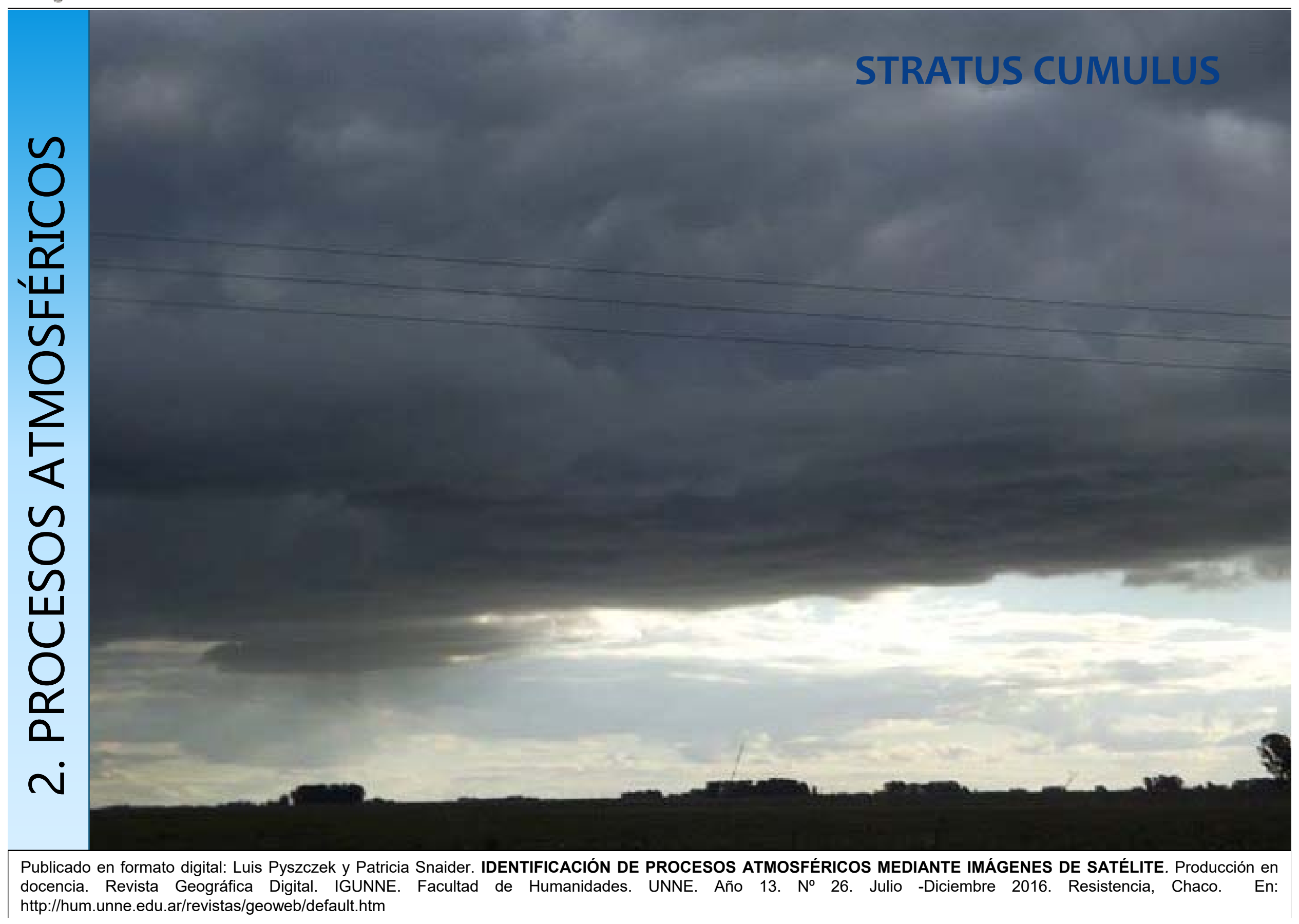




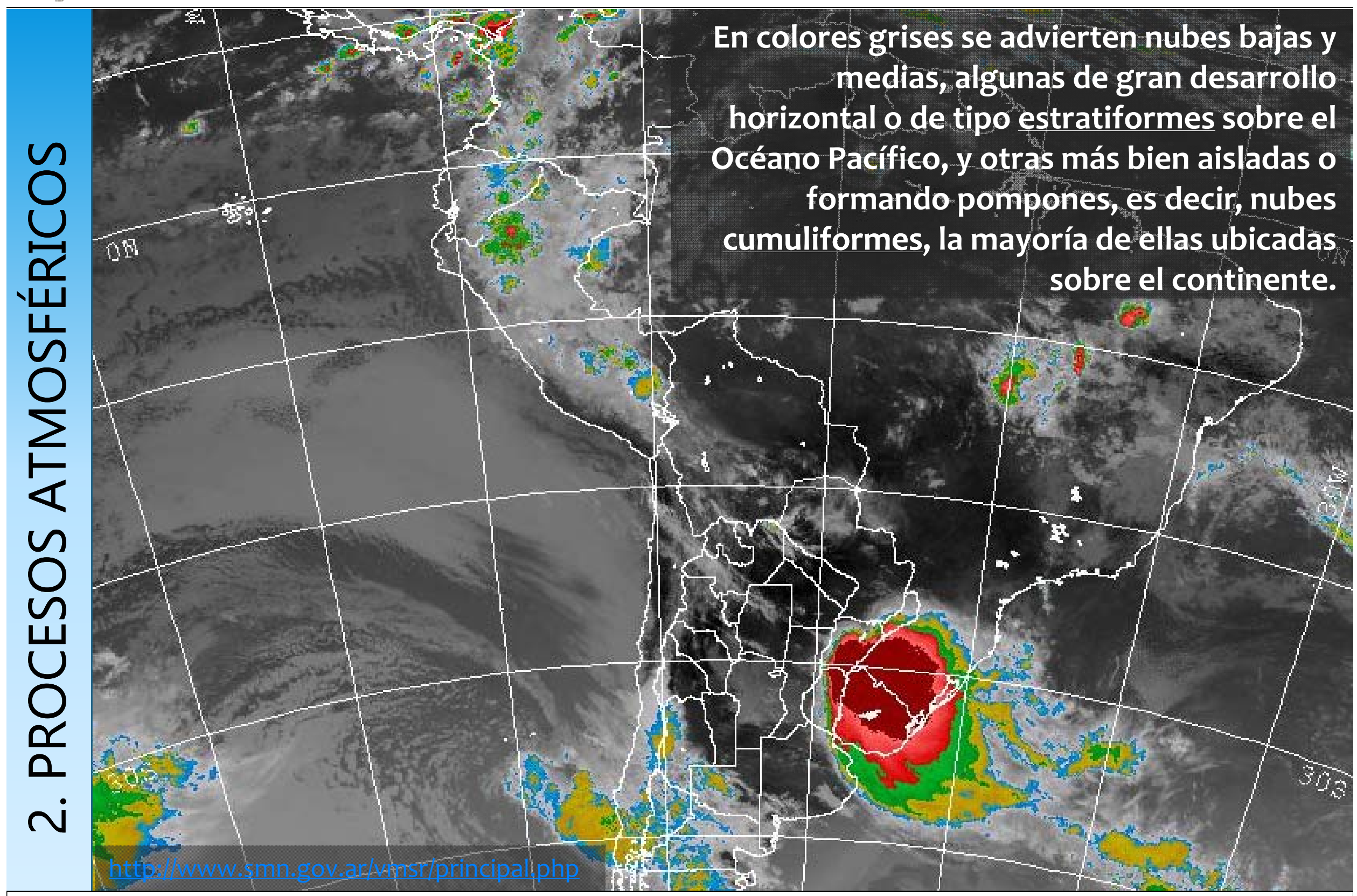

Publicado en formato digital: Luis Pyszczek y Patricia Snaider. IDENTIFICACIÓN DE PROCESOS ATMOSFÉRICOS MEDIANTE IMÁGENES DE SATÉLITE. Producción en docencia. Revista Geográfica Digital. IGUNNE. Facultad de Humanidades. UNNE. Año 13. No 26. Julio -Diciembre 2016. http://hum.unne.edu.ar/revistas/geoweb/default.htm 


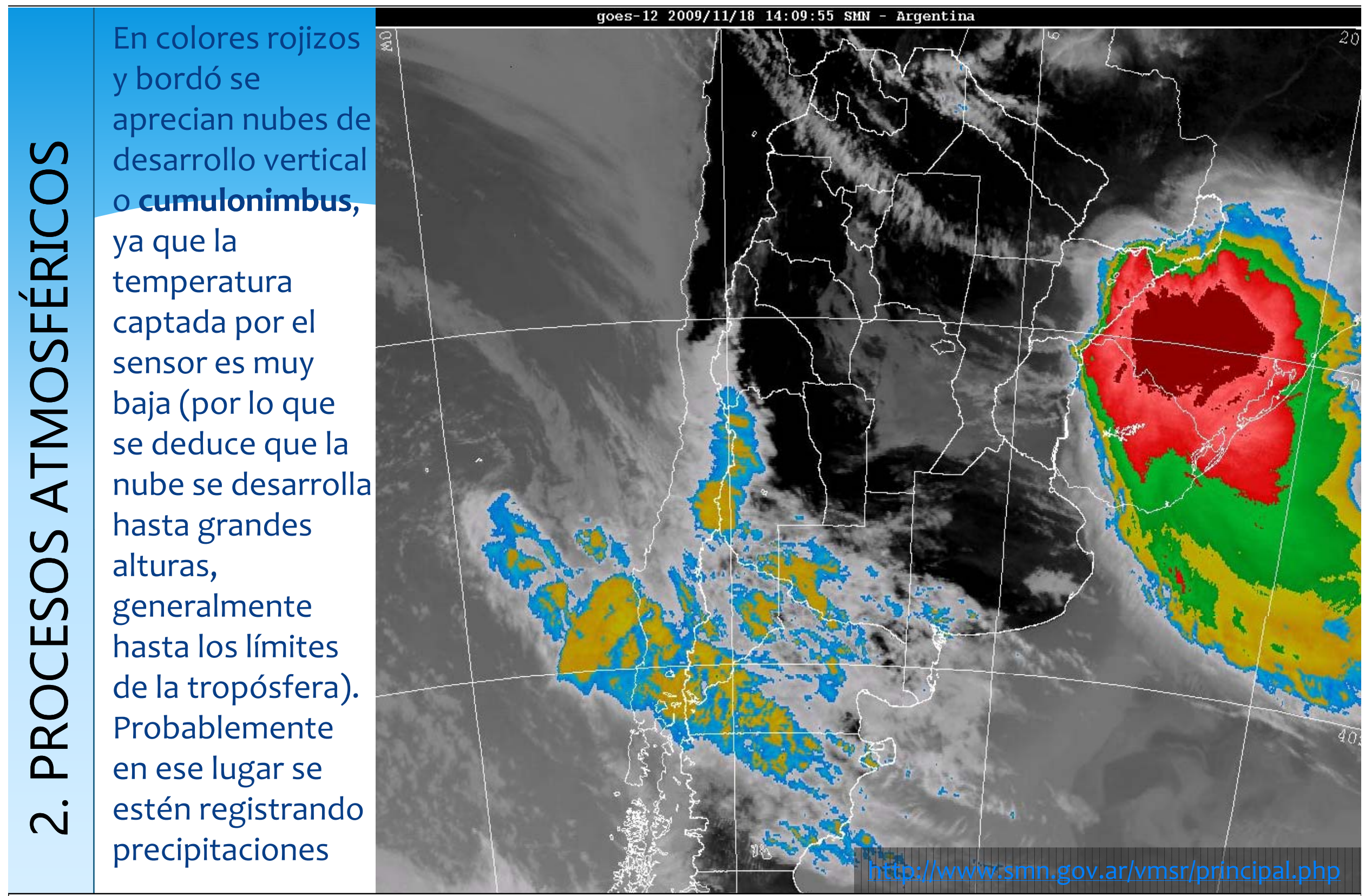

Publicado en formato digital: Luis Pyszczek y Patricia Snaider. IDENTIFICACIÓN DE PROCESOS ATMOSFÉRICOS MEDIANTE IMÁGENES DE SATÉLITE. Producción en docencia. Revista Geográfica Digital. IGUNNE. Facultad de Humanidades. UNNE. Año 13. No 26. Julio -Diciembre 2016. Resistencia, Chaco. En: http://hum.unne.edu.ar/revistas/geoweb/default.htm 


\section{NEFOANÁLISIS}

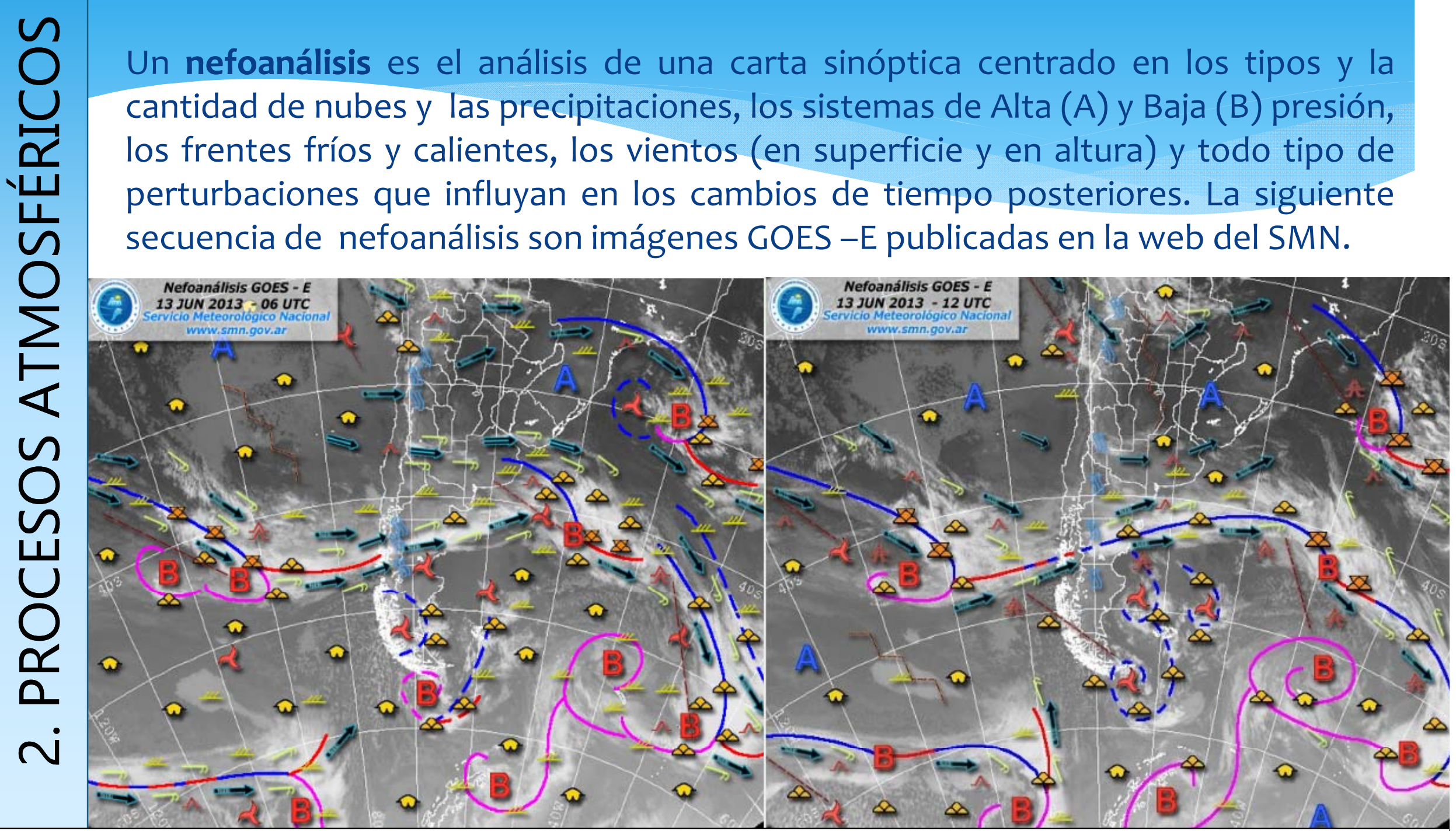

Publicado en formato digital: Luis Pyszczek y Patricia Snaider. IDENTIFICACIÓN DE PROCESOS ATMOSFÉRICOS MEDIANTE IMÁGENES DE SATÉLITE. Producción en docencia. Revista Geográfica Digital. IGUNNE. Facultad de Humanidades. UNNE. Año 13. No 26. Julio -Diciembre 2016. Resistencia, Chaco. En: http://hum.unne.edu.ar/revistas/geoweb/default.htm 


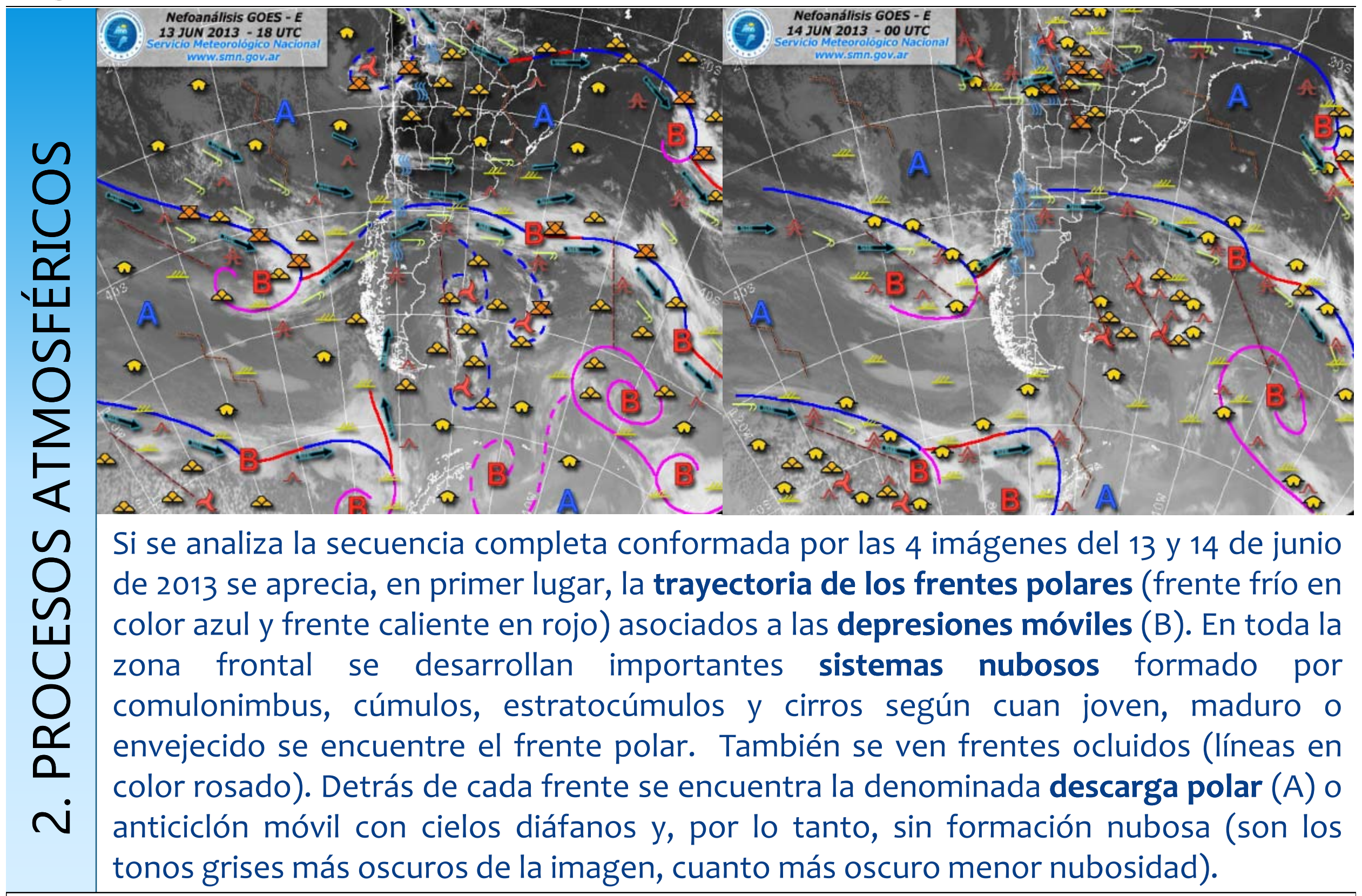

Publicado en formato digital: Luis Pyszczek y Patricia Snaider. IDENTIFICACIÓN DE PROCESOS ATMOSFÉRICOS MEDIANTE IMÁGENES DE SATÉLITE. Producción en docencia. Revista Geográfica Digital. IGUNNE. Facultad de Humanidades. UNNE. Año 13. No 26. Julio -Diciembre 2016.2 Resistencia, Chaco. En: http://hum.unne.edu.ar/revistas/geoweb/default.htm 


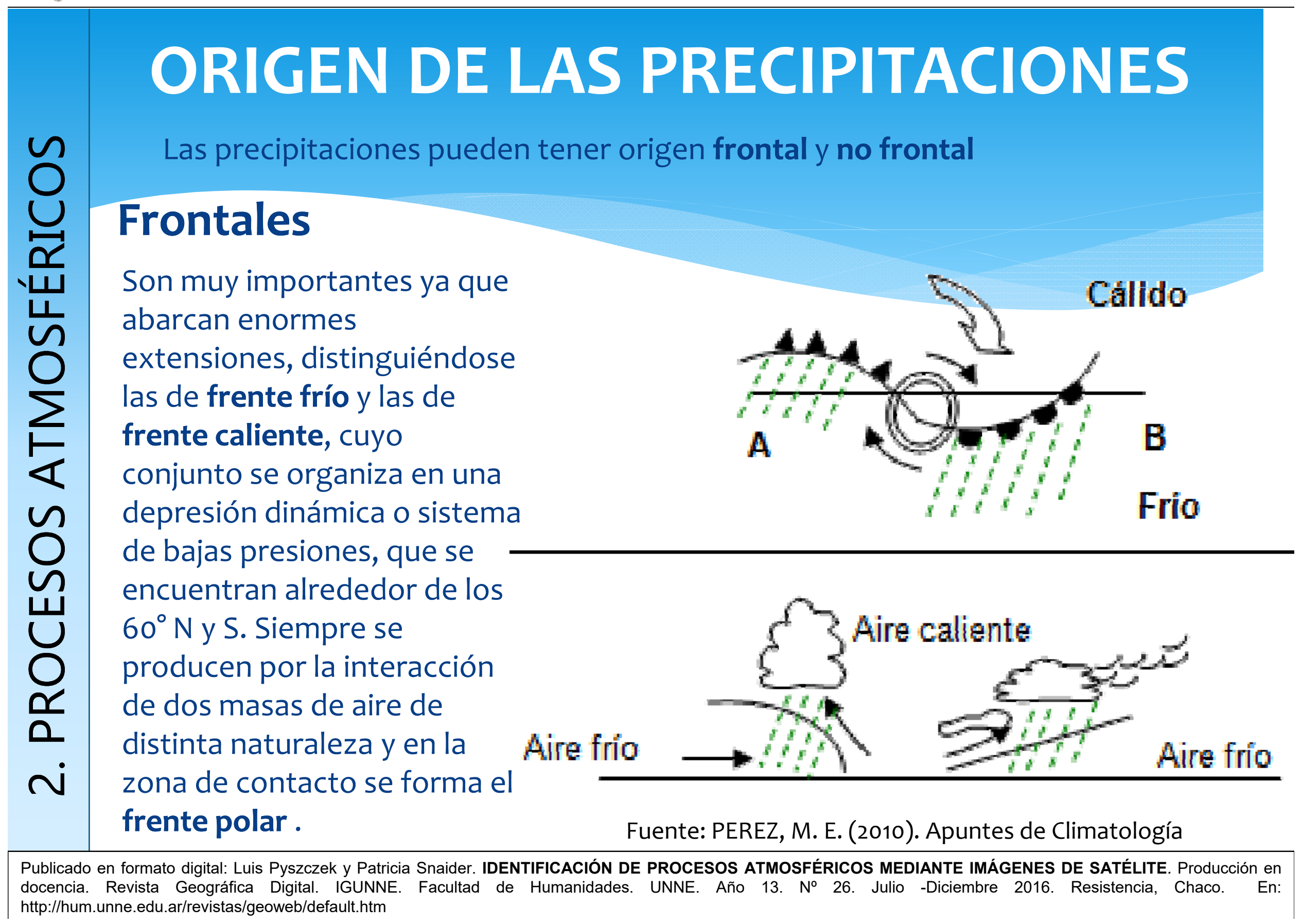




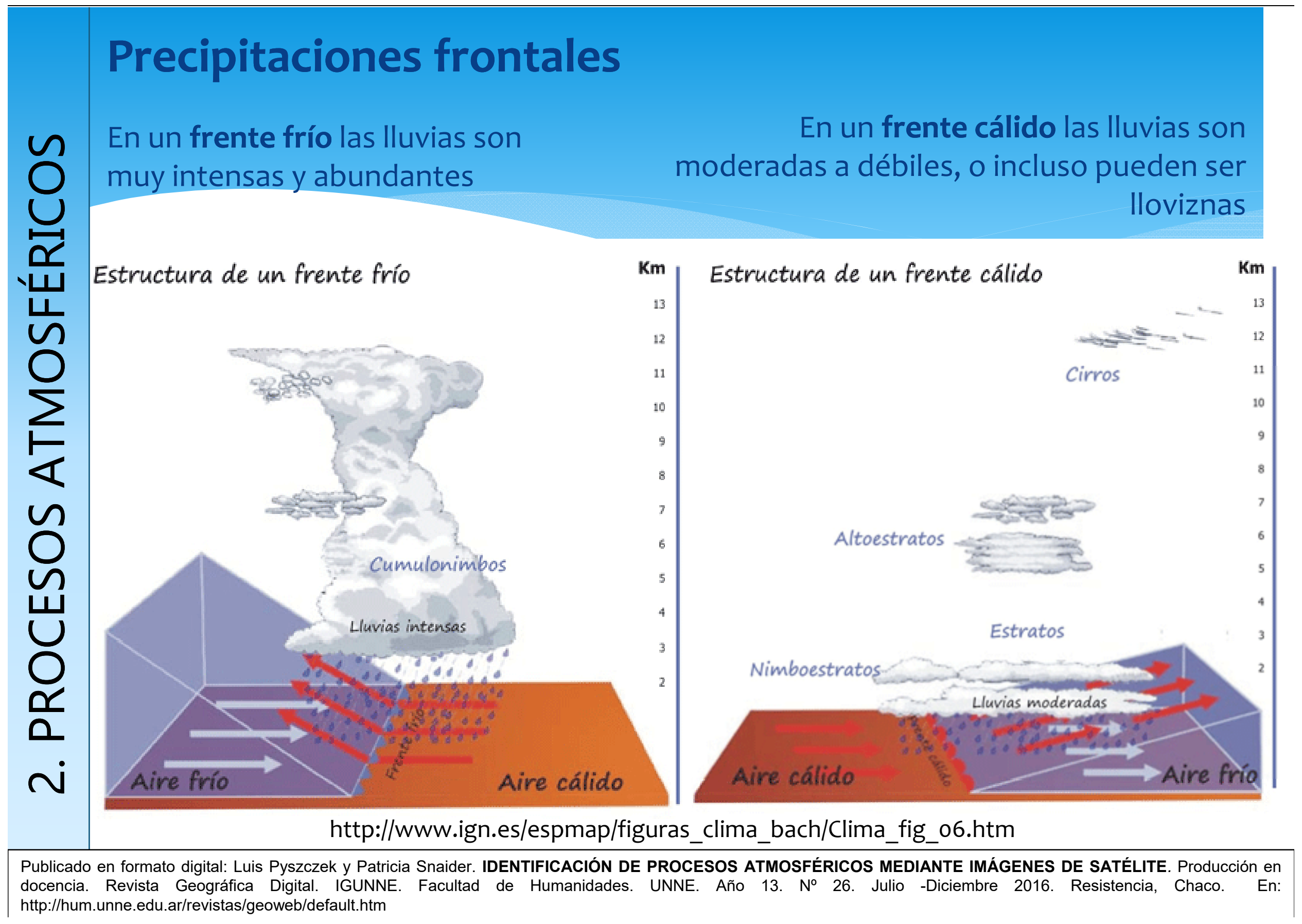




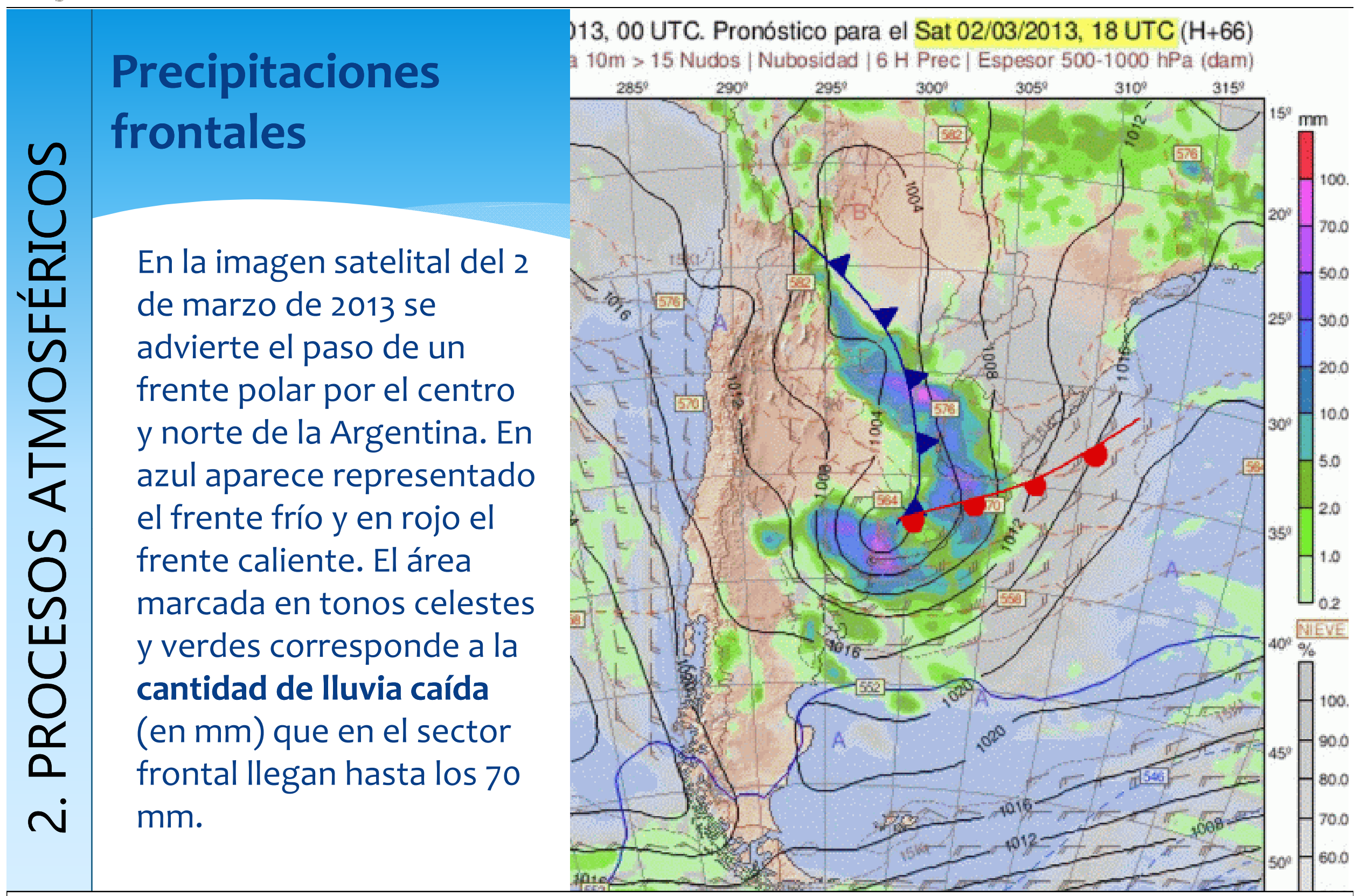

Publicado en formato digital: Luis Pyszczek y Patricia Snaider. IDENTIFICACIÓN DE PROCESOS ATMOSFÉRICOS MEDIANTE IMÁGENES DE SATÉLITE. Producción en docencia. Revista Geográfica Digital. IGUNNE. Facultad de Humanidades. UNNE. Año 13. No 26. Julio -Diciembre 2016. Resistencia, Chaco. En: http://hum.unne.edu.ar/revistas/geoweb/default.htm 


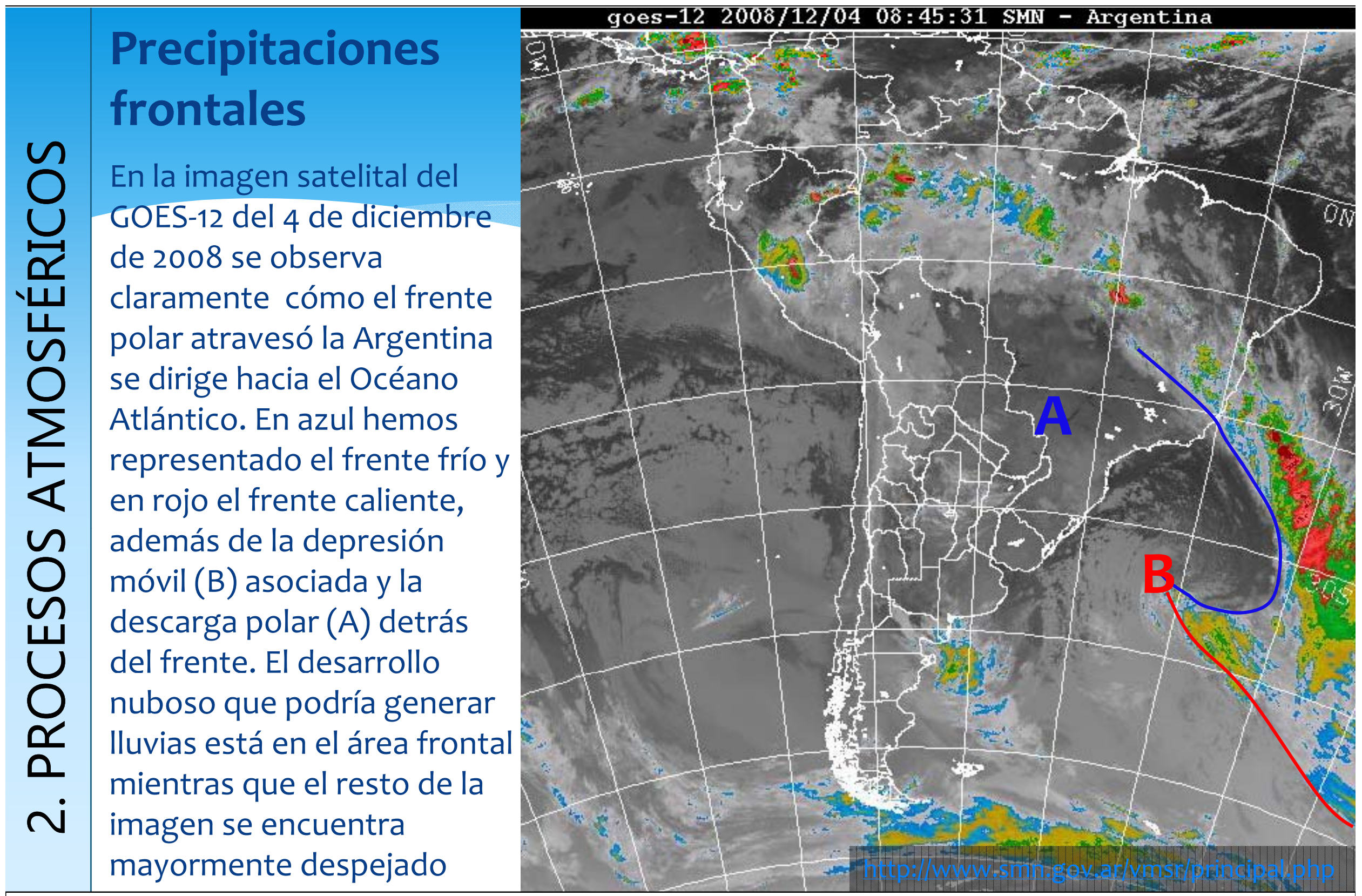

Publicado en formato digital: Luis Pyszczek y Patricia Snaider. IDENTIFICACIÓN DE PROCESOS ATMOSFÉRICOS MEDIANTE IMÁGENES DE SATÉLITE. Producción en docencia. Revista Geográfica Digital. IGUNNE. Facultad de Humanidades. UNNE. Año 13. No 26. Julio -Diciembre 2016. http://hum.unne.edu.ar/revistas/geoweb/default.htm 


\section{ORIGEN DE LAS PRECIPITACIONES}

\section{Oิ No frontales: convectivas}

En las precipitaciones no frontales interviene una sola masa de aire y se originan por movimientos de ascenso del aire, y debidas a diferentes causas:

- Lluvias de inestabilidad por calentamiento in situ o de inestabilidad desorganizada

- Lluvias de inestabilidad organizada, Iluvias prefrontales o de inestabilidad prefrontal

- Lluvias por desplazamiento de una masa de aire hacia áreas más cálidas

- Ciclones tropicales o huracanes

También veremos en una imagen satelital el tipo y la distribución de la nubosidad en un día de lloviznas. 


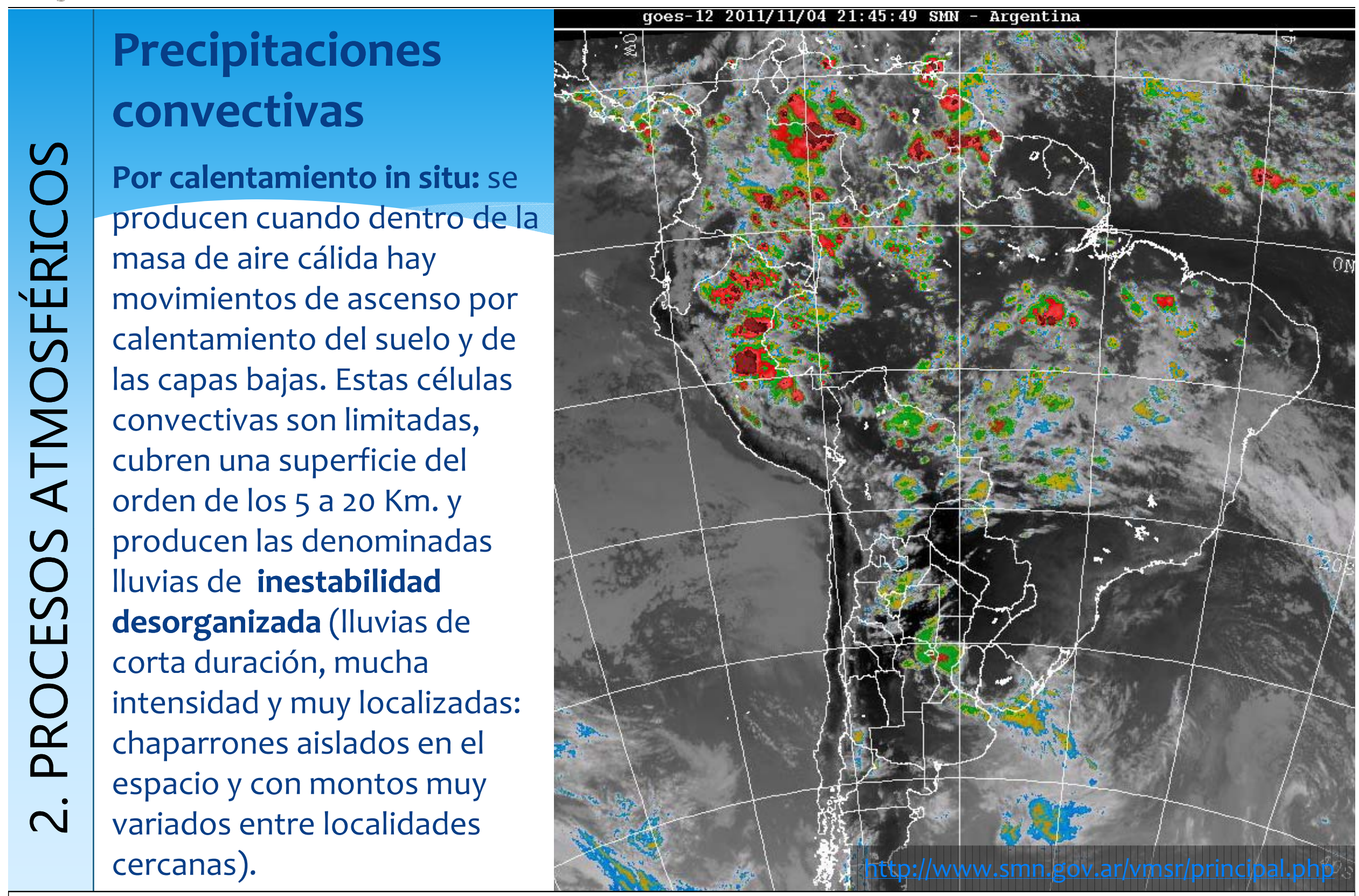

Publicado en formato digital: Luis Pyszczek y Patricia Snaider. IDENTIFICACIÓN DE PROCESOS ATMOSFÉRICOS MEDIANTE IMÁGENES DE SATÉLITE. Producción en docencia. Revista Geográfica Digital. IGUNNE. Facultad de Humanidades. UNNE. Año 13. No 26. Julio -Diciembre 2016. http://hum.unne.edu.ar/revistas/geoweb/default.htm 


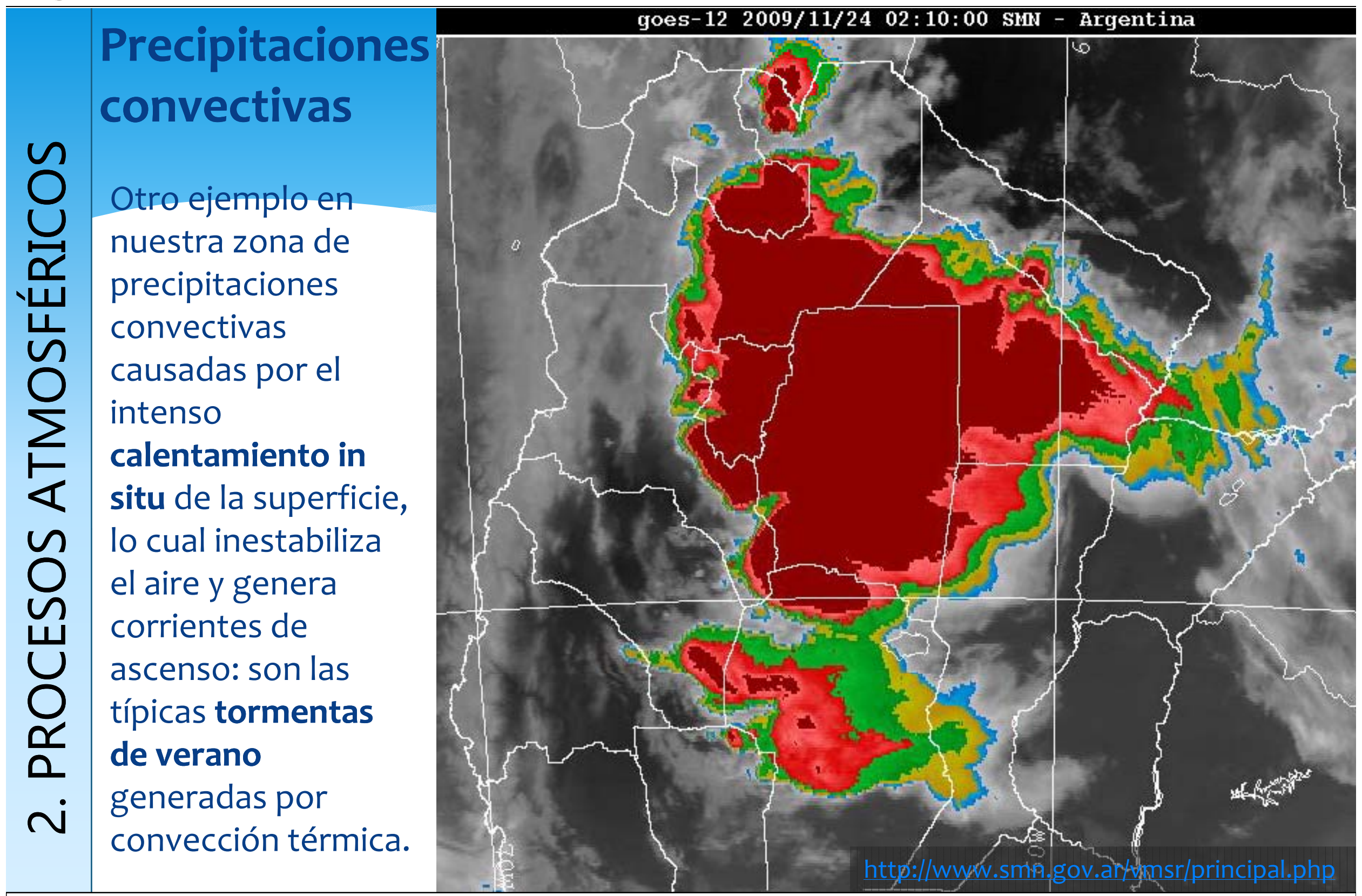

Publicado en formato digital: Luis Pyszczek y Patricia Snaider. IDENTIFICACIÓN DE PROCESOS ATMOSFÉRICOS MEDIANTE IMÁGENES DE SATÉLITE. Producción en docencia. Revista Geográfica Digital. IGUNNE. Facultad de Humanidades. UNNE. Año 13. No 26. Julio -Diciembre 2016. http://hum.unne.edu.ar/revistas/geoweb/default.htm 


\section{Precipitaciones convectivas}

La línea de inestabilidad
organizada se produce
cuando en el continente hay
un frente frío que avanza
muy lentamente y al mismo
tiempo ingresa aire cálido
desde el Atlántico. El aire
cálido, como tiene más
velocidad, al encontrarse con
el frente frío se frena, se
acumula en la base del
mismo, genera convergencia
y asciende, ascenso que
produce condensación y
precipitación varios km
delante del frente frío, de allí
que también se la denomina
Iluvia prefrontal o de
inestabilidad prefrontal.

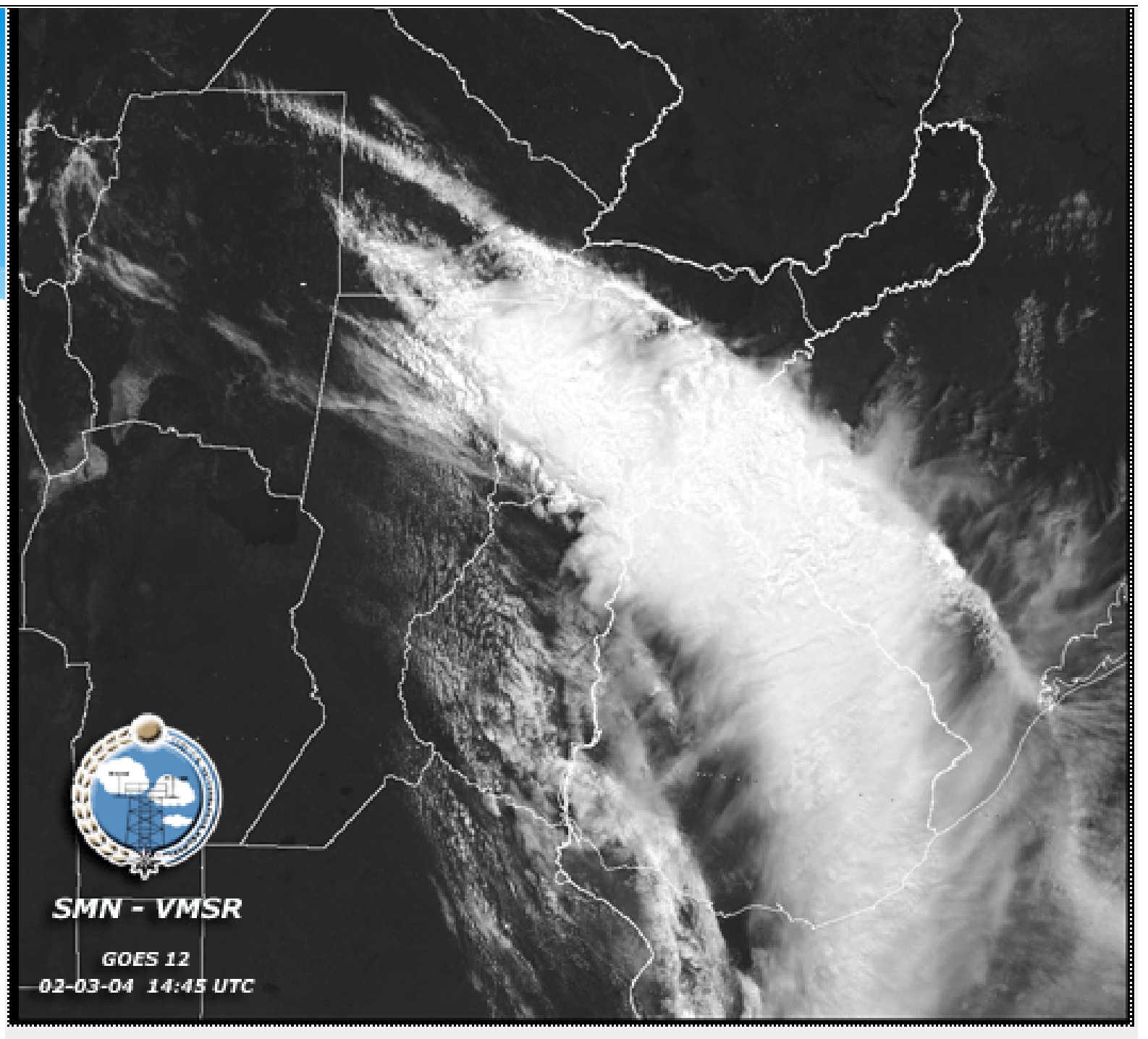

Imagen del satélite GOES 12 en canal visible con resolución de $1 \mathrm{~km}$ en la que se observa claramente una alineación nubosa por delante de un sistema frontal frío que se desplaza hacia el Noreste. Estas nubes, con desarrollos verticales importantes, pueden llegar a producir tiempo severo.

Publicado en formato digital: Luis Pyszczek y Patricia Snaider. IDENTIFICACIÓN DE PROCESOS ATMOSFÉRICOS MEDIANTE IMÁGENES DE SATÉLITE. Producción en docencia. Revista Geográfica Digital. IGUNNE. Facultad de Humanidades. UNNE. Año 13. No 26. Julio -Diciembre 2016. http://hum.unne.edu.ar/revistas/geoweb/default.htm 


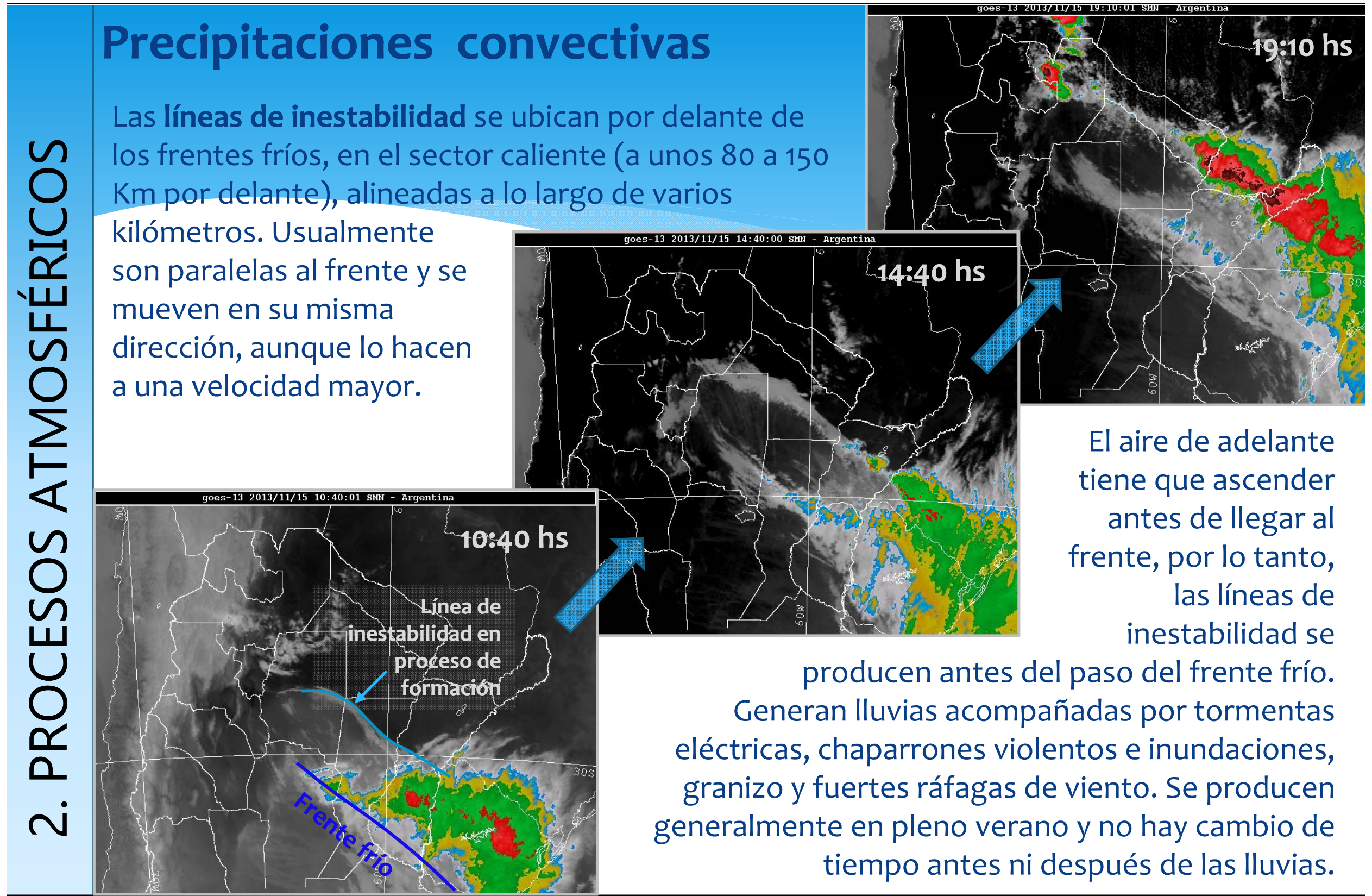

Publicado en formato digital: Luis Pyszczek y Patricia Snaider. IDENTIFICACIÓN DE PROCESOS ATMOSFÉRICOS MEDIANTE IMÁGENES DE SATÉLITE. Producción en docencia. Revista Geográfica Digital. IGUNNE. Facultad de Humanidades. UNNE. Año 13. No 26. Julio -Diciembre 2016. Resistencia, Chaco. En: http://hum.unne.edu.ar/revistas/geoweb/default.htm 


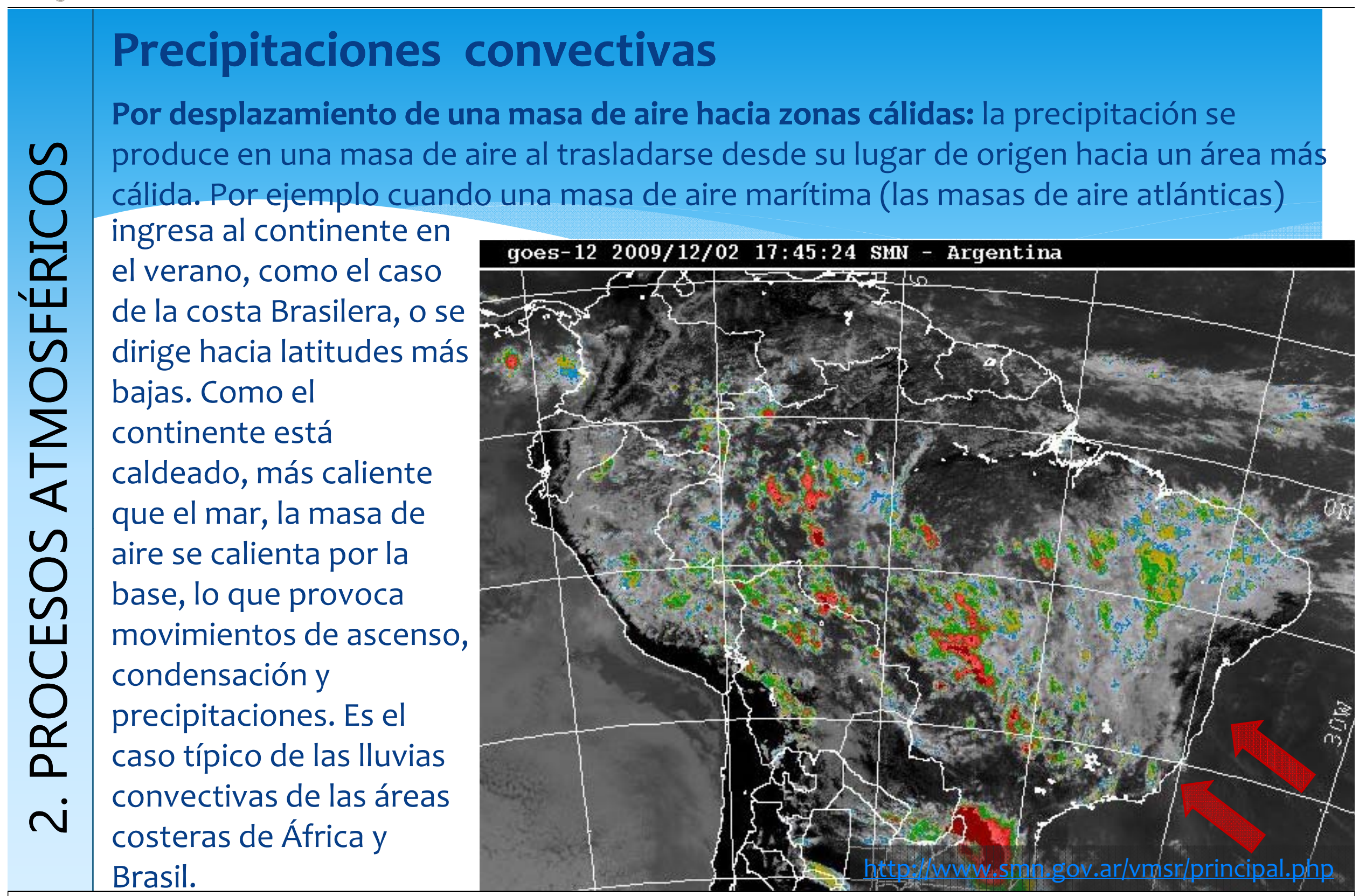

Publicado en formato digital: Luis Pyszczek y Patricia Snaider. IDENTIFICACIÓN DE PROCESOS ATMOSFÉRICOS MEDIANTE IMÁGENES DE SATÉLITE. Producción en docencia. Revista Geográfica Digital. IGUNNE. Facultad de Humanidades. UNNE. Año 13. No 26. Julio -Diciembre 2016.2 Resistencia, Chaco. En: http://hum.unne.edu.ar/revistas/geoweb/default.htm 


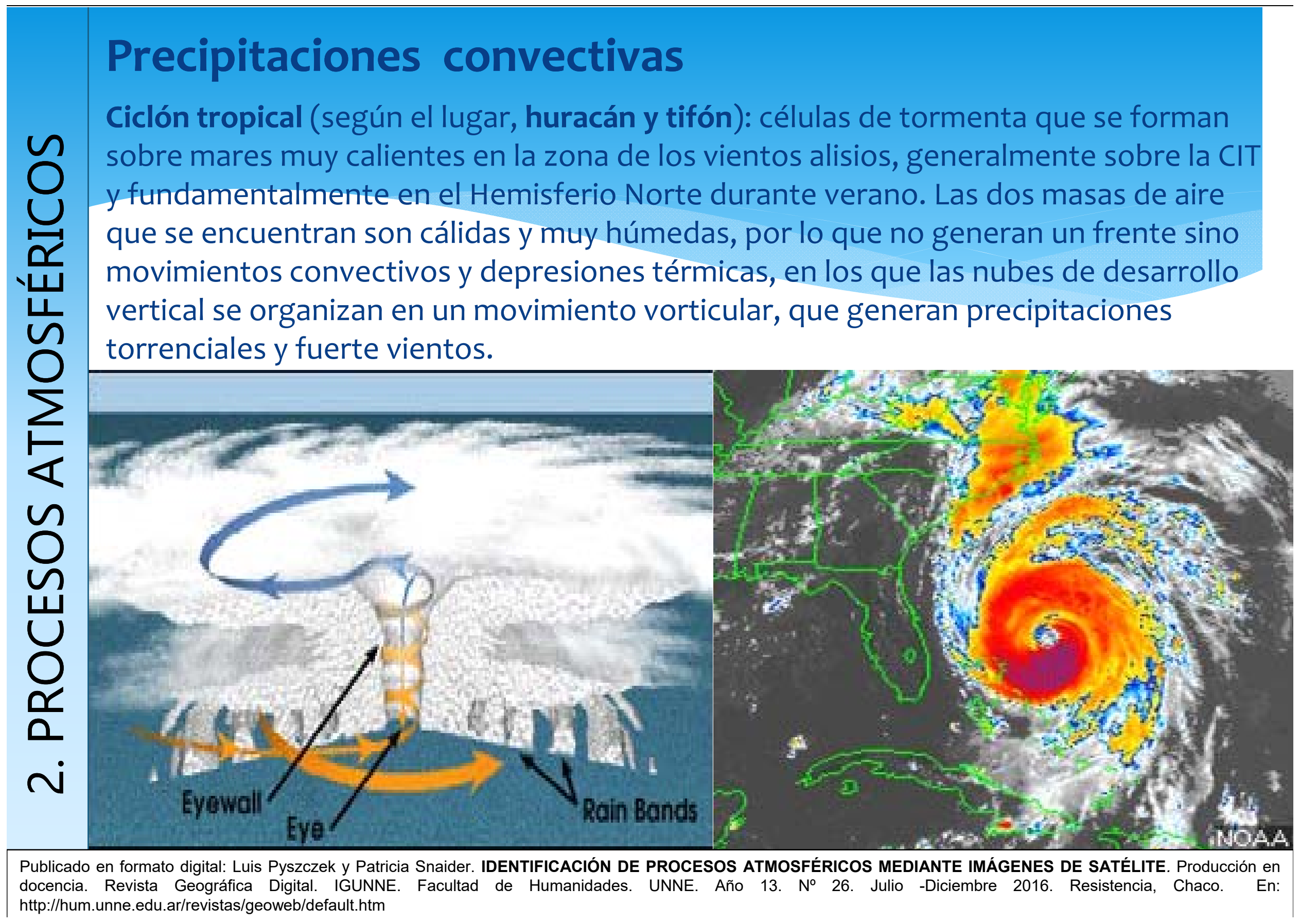




\section{Precipitaciones convectivas}

Un huracán es un fenómeno meteorológico violento que se origina sobre los océanos tropicales y que se traslada miles de kilómetros sobre el océano, capturando la energía calorífica de las aguas templadas. El viento puede llegar a alcanzar velocidades de 250 $\mathrm{km} / \mathrm{h}$ aunque los valores más habituales se encuentran alrededor de $119 \mathrm{~km} / \mathrm{h}$.

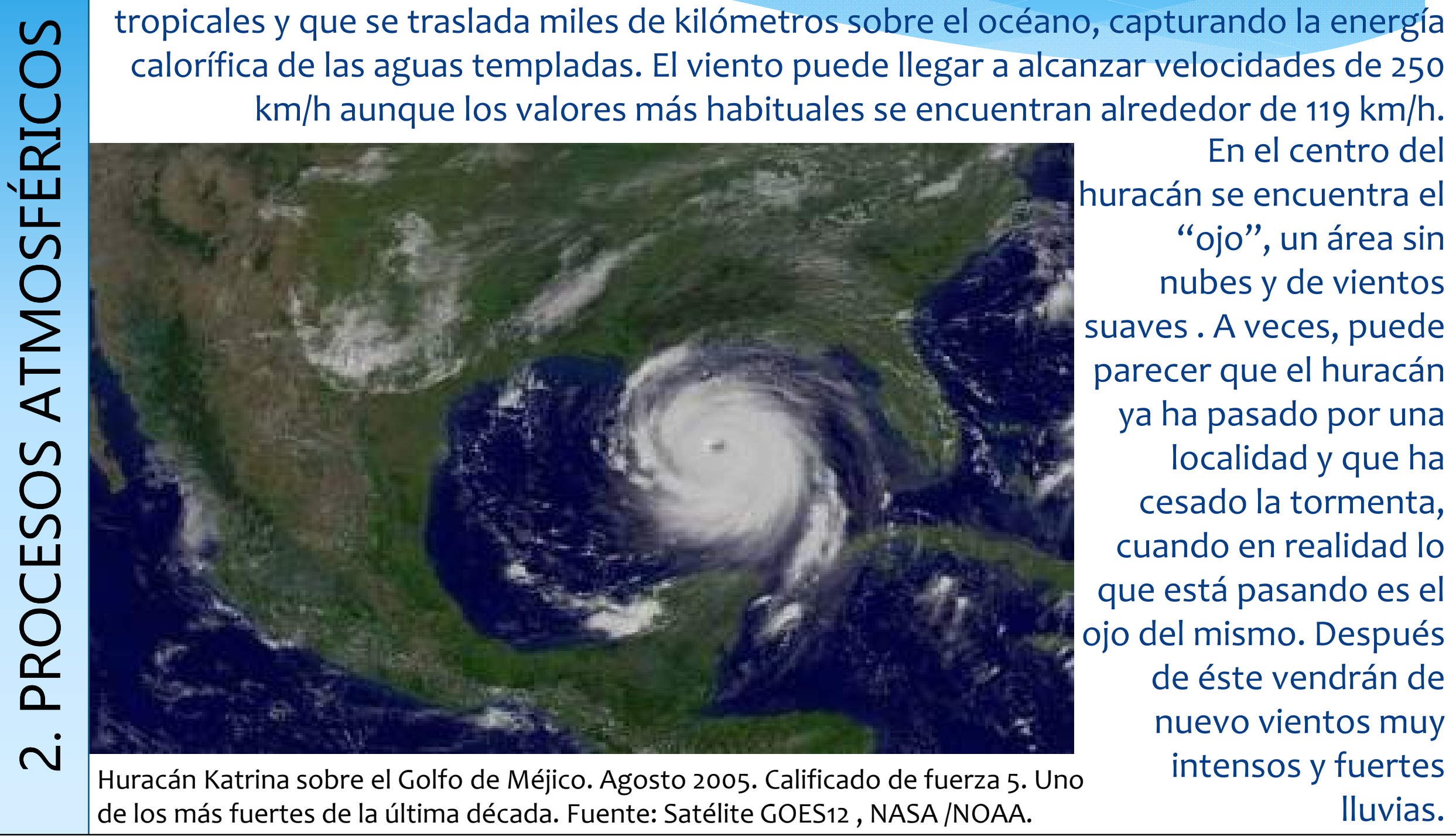

Publicado en formato digital: Luis Pyszczek y Patricia Snaider. IDENTIFICACIÓN DE PROCESOS ATMOSFÉRICOS MEDIANTE IMÁGENES DE SATÉLITE. Producción en docencia. Revista Geográfica Digital. IGUNNE. Facultad de Humanidades. UNNE. Año 13. No 26. Julio -Diciembre 2016. Resistencia, Chaco. En: http://hum.unne.edu.ar/revistas/geoweb/default.htm 


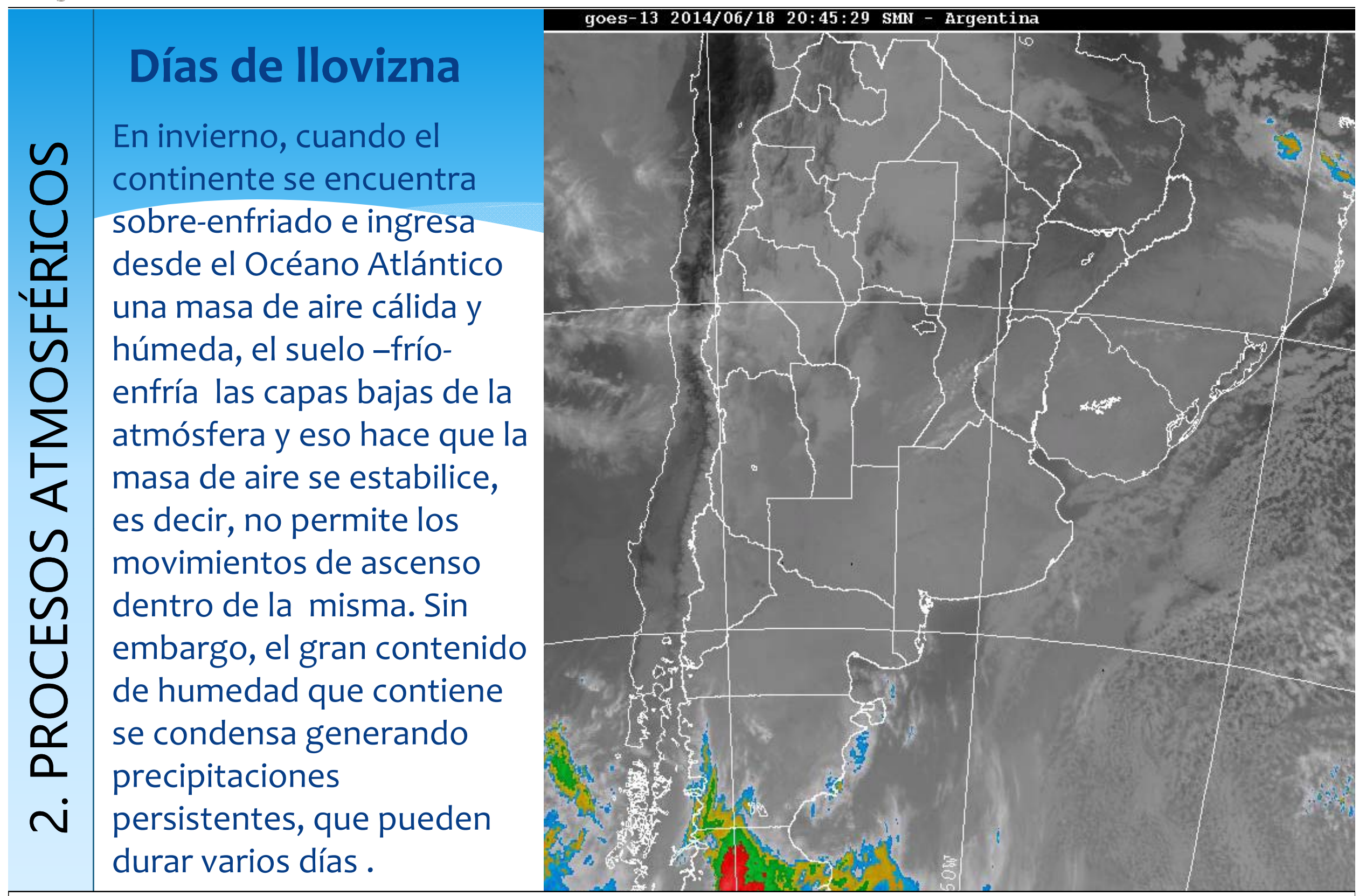

Publicado en formato digital: Luis Pyszczek y Patricia Snaider. IDENTIFICACIÓN DE PROCESOS ATMOSFÉRICOS MEDIANTE IMÁGENES DE SATÉLITE. Producción en docencia. Revista Geográfica Digital. IGUNNE. Facultad de Humanidades. UNNE. Año 13. No 26. Julio -Diciembre 2016.2 Resistencia, Chaco. En: http://hum.unne.edu.ar/revistas/geoweb/default.htm 


\begin{tabular}{l|l} 
Esta imagen, que sirve para \\
detectar las heladas \\
producidas, por ejemplo, el \\
20 de noviembre de 2015, \\
muestra la temperatura de \\
superficie antes de la salida \\
del sol. La imagen pertenece \\
a la serie de satélites NoAA y \\
GOES y es capturada por las \\
antenas que posee el \\
Instituto de Clima y Agua del \\
InTA - Castelar.
\end{tabular}

TEMPERATURA DE SUPERFICIE - SATÉLTTE NOAA-18

20 de Noviembre de 2015 - Horario de Pasaje: 06:25 hs Resolución: $1000 \mathrm{~m}$

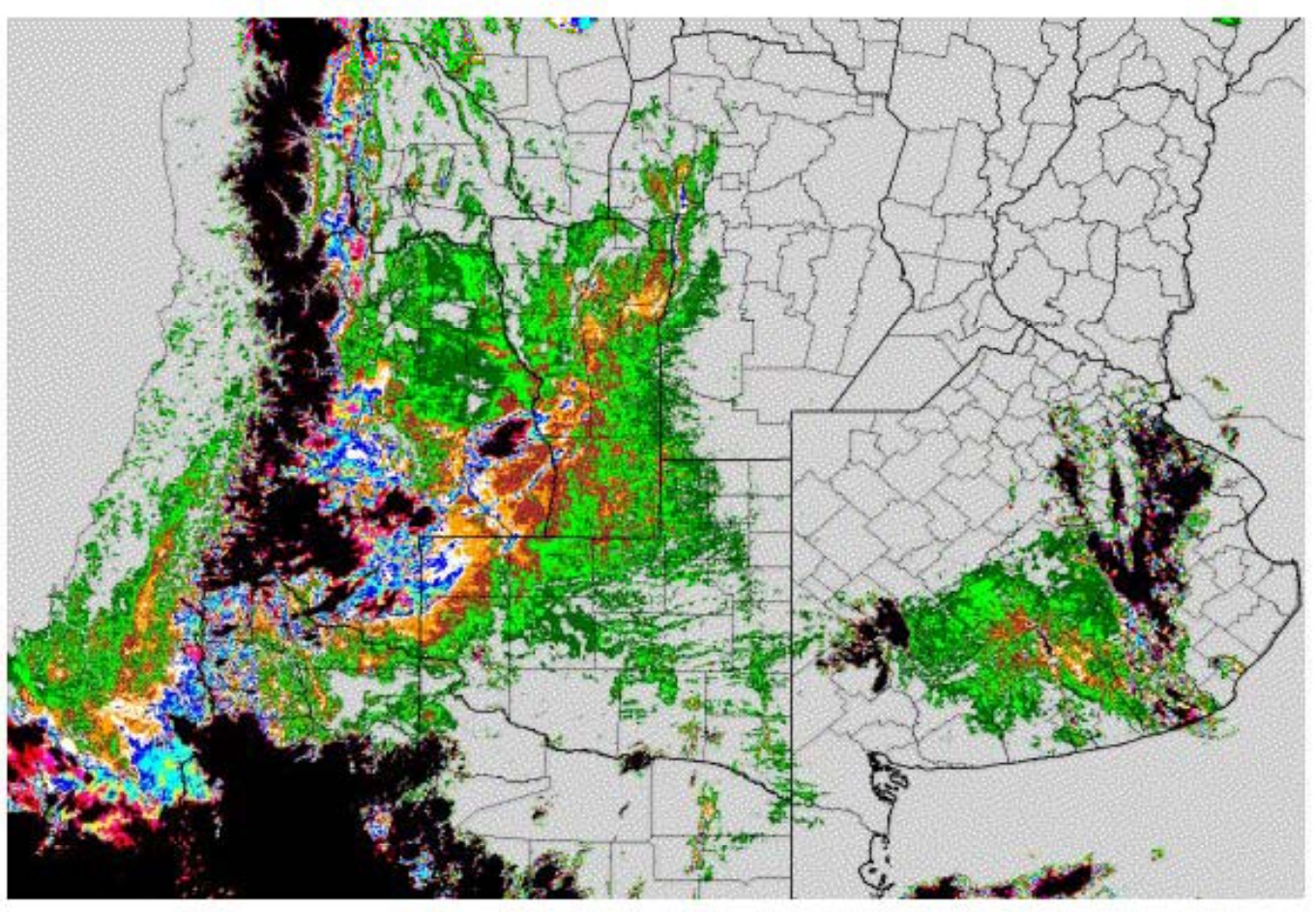

http://radar.inta.gov.ar/echotops/Rad_INTA_Echotops.htm Referencias

\begin{tabular}{|c|c|c|c|c|c|c|c|c|c|c|c|}
\hline $\begin{array}{l}\text { entre } \\
-5 y-6^{\circ} \mathrm{C}\end{array}$ & $\begin{array}{c}\text { entre } \\
-4 y-5 \text { oc }\end{array}$ & $\begin{array}{c}\text { entre } \\
-3 y-4{ }^{\circ} \mathrm{C}\end{array}$ & $\begin{array}{c}\text { entre } \\
-3 y-2{ }^{\circ} \mathrm{C}\end{array}$ & $\begin{array}{c}\text { entre } \\
-2 y-1 \propto C\end{array}$ & $\begin{array}{c}\text { entre } \\
0 y-1{ }^{\circ} \mathrm{C}\end{array}$ & $\begin{array}{c}\text { entre } \\
0 \text { y } 1^{\circ} \mathrm{C}\end{array}$ & $\begin{array}{c}\text { entre } \\
1 \text { y } 2^{\circ} \mathrm{C}\end{array}$ & $\begin{array}{c}\text { entre } \\
2 \text { प } 3^{\circ} \mathrm{C}\end{array}$ & $\begin{array}{c}\text { entre } \\
3 \text { y } 4^{\circ} \mathrm{C}\end{array}$ & $\begin{array}{l}\text { Mayor a } \\
4^{\circ} \mathrm{C}\end{array}$ & $\begin{array}{l}\text { Nubes y } \\
<-60^{\circ} \mathrm{C}\end{array}$ \\
\hline
\end{tabular}

Publicado en formato digital: Luis Pyszczek y Patricia Snaider. IDENTIFICACIÓN DE PROCESOS ATMOSFÉRICOS MEDIANTE IMÁGENES DE SATÉLITE. Producción en docencia. Revista Geográfica Digital. IGUNNE. Facultad de Humanidades. UNNE. Año 13. No 26. Julio -Diciembre 2016. Resistencia, Chaco. En: http://hum.unne.edu.ar/revistas/geoweb/default.htm 


\section{TEMPERATURA DEL MAR}

Las radiaciones infrarrojas térmicas son intensamente absorbidas por el agua. Las
medidas de temperatura que se obtienen corresponden a una capa superficial de
pocos milímetros de espesor (temperatura de piel) y van a ser algo superiores a la de
aguas más profundas. Sin embargo, como a través de esa "piel" ocurren importantes
procesos de intercambio térmico entre el mar y la atmósfera, estas medidas de
temperatura son de fundamental
importancia para estudios
climáticos a nivel global.
Las observaciones de temperatura
superficial del mar son muy
importantes para los
oceanógrafos puesto que
permiten el análisis espacial y
temporal de las corrientes
oceánicas así como de sus
variaciones. Incluso facilitan el
pronóstico de desastres climáticos
como los inducidos por la
corriente de El Niño.

Publicado en formato digital: Luis Pyszczek y Patricia Snaider. IDENTIFICACIÓN DE PROCESOS ATMOSFÉRICOS MEDIANTE IMÁGENES DE SATÉLITE. Producción en docencia. Revista Geográfica Digital. IGUNNE. Facultad de Humanidades. UNNE. Año 13. No 26. Julio -Diciembre 2016. Resistencia, Chaco. En: http://hum.unne.edu.ar/revistas/geoweb/default.htm 


\section{TEMPERATURA DEL MAR}

Fenómeno de El Niño: consiste en un conjunto de alteraciones que tienen lugar en el
Pacífico oriental a intervalos de tiempo irregulares, por lo general de cuatro a siete años. Su origen se atribuye a procesos complejos de interacción océano-atmósfera, algunos aún poco comprendidos, y con efectos desastrosos a nivel global.
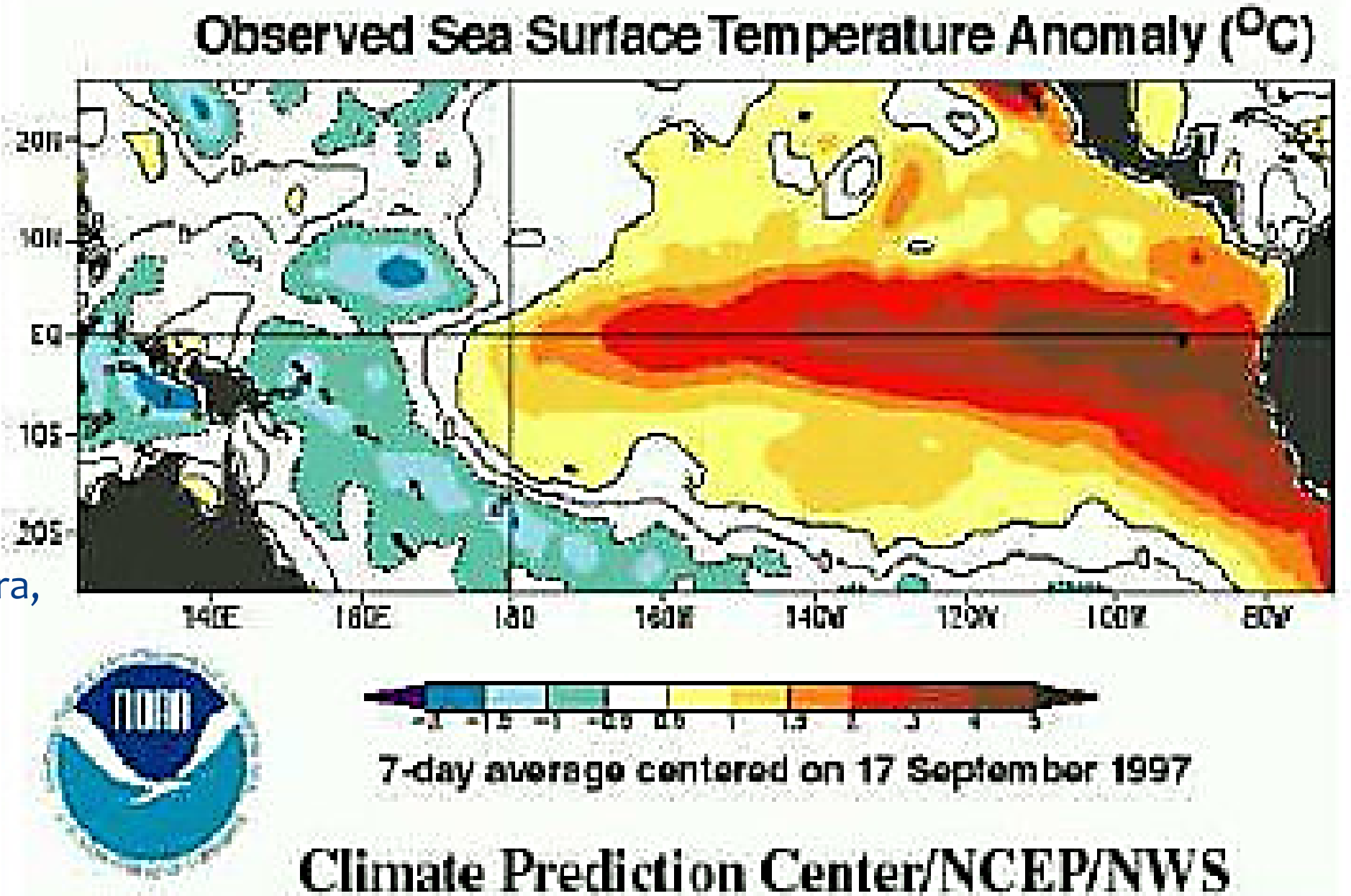

7 -day awerago conterod on 17 Soptom bor 1997

\section{Climate Prediction Center/NCEP/NWS}

Publicado en formato digital: Luis Pyszczek y Patricia Snaider. IDENTIFICACIÓN DE PROCESOS ATMOSFÉRICOS MEDIANTE IMÁGENES DE SATÉLITE. Producción en docencia. Revista Geográfica Digital. IGUNNE. Facultad de Humanidades. UNNE. Año 13. No 26. Julio -Diciembre 2016. Resistencia, Chaco. En: http://hum.unne.edu.ar/revistas/geoweb/default.htm 


\section{BIBLIOGRAFÍA}

* PASELK, R. (2002): Estructura atómica y la radiación electromagnética (luz). Universidad Estatal Humboldt.

Disponible

en:

http://users.humboldt.edu/rpaselk/C109.S08/C109_Notes/C109_lec19.htm

* PEREZ, M. E. (2010): Apuntes de Climatología. Facultad de Humanidades. UNNE.

* RODRÍGUEZ JIMÉNEZ R., CAPA A., PORTELA LOZANO A. (2004): Meteorología y Climatología, Semana de la Ciencia y la Tecnología 2004. FECYT (Fundación Española para la Ciencia y la Tecnología).

* TELEDET (2015): Teoría e Imágenes Satelitales. Uruguay. Disponible en: http://www.teledet.com.uy/

* ZAMORA VAGAS,

http://zamoravagasandrsatelites.blogspot.com.co/2010/11/satelites.html

\section{PÁGINAS WEB CONSULTADAS:}

* AEMet (Agencia Estatal de Meteorología de España). Disponible en: http://www.aemet.es/es/portada

* CONAGUA (Comisión Nacional del Agua) México. Disponible en: http://www.conagua.gob.mx/

* IGM (Instituto Geográfico Militar) Chile. Disponible en: https://www.igm.cl/

* INEGI (Instituto Nacional de Estadística y Geografía) México. Disponible en: http://www.inegi.org.mx/geo/contenidos/imgpercepcion/imgsatelite/

* INTA (Instituto Nacional de Tecnología Agropecuaria): clima y agua . Disponible en: http://climayagua.inta.gov.ar/heladas

* SMN (Servicio Meteorológico Nacional). Argentina. Disponible en: http://www.smn.gov.ar/

Publicado en formato digital: Luis Pyszczek y Patricia Snaider. IDENTIFICACIÓN DE PROCESOS ATMOSFÉRICOS MEDIANTE IMÁGENES DE SATÉLITE. Producción en docencia. Revista Geográfica Digital. IGUNNE. Facultad de Humanidades. UNNE. Año 13. No 26. Julio -Diciembre 2016. http://hum.unne.edu.ar/revistas/geoweb/default.htm 